Review

\title{
Volatile Compounds of Raspberry Fruit: From Analytical Methods to Biological Role and Sensory Impact
}

\author{
Eugenio Aprea *, Franco Biasioli and Flavia Gasperi \\ Department of Food Quality and Nutrition, Research and Innovation Centre, Fondazione Edmund Mach, \\ 38010 San Michele all'Adige (TN), Italy; E-Mails: franco.biasioli@fmach.it (F.B.); \\ flavia.gasperi@fmach.it (F.G.)
}

* Author to whom correspondence should be addressed; E-Mail: eugenio.aprea@fmach.it; Tel.: +39-0461-615-388; Fax: +39-0461-615-200.

Academic Editor: Riccardo Flamini

Received: 3 November 2014 / Accepted: 22 January 2015 / Published: 30 January 2015

\begin{abstract}
Volatile compounds play a key role in the formation of the well-recognized and widely appreciated raspberry aroma. Studies on the isolation and identification of volatile compounds in raspberry fruit (Rubus idaeus L.) are reviewed with a focus on aroma-related compounds. A table is drawn up containing a comprehensive list of the volatile compounds identified so far in raspberry along with main references and quantitative data where available. Two additional tables report the glycosidic bond and enantiomeric distributions of the volatile compounds investigated up to now in raspberry fruit. Studies on the development and evolution of volatile compounds during fruit formation, ripening and senescence, and genetic and environmental influences are also reviewed. Recent investigations showing the potential role of raspberry volatile compounds in cultivar differentiation and fruit resistance to mold disease are reported as well. Finally a summary of research done so far and our vision for future research lines are reported.
\end{abstract}

Keywords: raspberry (Rubus idaeus L.); volatile organic compounds; flavor; aroma; glycosidically-bound volatiles; enantiomers; headspace analysis; odor active compounds; Botrytis 


\section{Introduction}

Raspberry (Rubus idaeus L.) is a member of the Rosaceae family producing a red fruit with a sweet but tart flavor. Some cultivars with recessive genes giving an extremely low concentrations of anthocyanin produce yellow berries [1], but it is the European red fruited cultivars that are most widely grown and economically most important. Although it is called a berry, the fruit produced by the raspberry is, in botanical terminology, a collection of numerous drupelets around a central core. The drupelets typically separate from the core when pickled.

This commodity is of continuously increasing economic importance, as witnessed by nearly 50 raspberry breeding programs around the world [2] and the ongoing raspberry sequencing project [3].

Red raspberries contain high amounts of polyphenols and antioxidants, and have a unique phytochemical profile rich in ellagitannins and anthocyanins that distinguishes them from other berries and fruits [4] and has positive implications for human health and the prevention of chronic diseases [5], although these fruits are mostly recognized and appreciated for their characteristic flavor. Volatile compounds play a key role in the formation of the flavor of food products and nearly 300 volatile compounds have so far been reported in raspberry. Volatile organic compounds (VOCs) are organic molecules with appreciable vapor pressure at ordinary room temperature. They are usually small molecules with a molecular weight lower than 300 Dalton. People often associate scents with volatiles that can be perceived by the human nose and have a pleasant smell [6] and flavor. It should be mentioned that volatile compounds in plants have various ecological and productive impacts: they attract pollinating insects, advertise that fruit are ripe and ready for seed dispersal, modulate systemic acquired resistance to pests and diseases, and also seem to alleviate abiotic stress [7].

Despite the economic and nutraceutical importance of raspberry, there has been little mention in the literature over last ten years of the volatile compounds in this fruit. A series of studies carried out by Firmenich in the '60s and '70s defined the basic methodologies and listed the compounds isolated and identified in raspberries. Of these, 4-(4-hydroxyphenyl)butan-2-one was recognized as the key compound in defining typical raspberry flavor and was therefore named "raspberry ketone". In the following decades only a few investigations on volatile compounds in raspberry were carried out and very little is known about the real impact the different volatile compounds have on human sensory perception or about their role in pest defense.

This paper reviews the studies carried out on the isolation and identification of volatile compounds in Rubus idaeus L. focusing on aroma-related compounds, from the pioneering application of separation methods to the most recent investigations. Table 1 lists all the volatile compounds identified in raspberry up to now, with main references and, where available, quantitative data. Two additional tables report the glycosidic bond and enantiomeric distributions of volatile compounds investigated in raspberry fruit. Studies on volatile compound development and evolution during fruit formation, ripening and senescence, and genetic and environmental influences are also reviewed. Finally, we look at recent investigations showing the potential role of raspberry volatile compounds in cultivar differentiation and fruit resistance to mold disease. 
Table 1. Reported volatile compounds in raspberry fruit (Rubus idaeus L.)

\begin{tabular}{|c|c|c|c|c|}
\hline & \multirow{2}{*}{ Compounds } & \multirow{2}{*}{$\begin{array}{c}\text { Quantitative Data } \\
(\mathbf{m g} / \mathbf{K g})\end{array}$} & \multicolumn{2}{|c|}{ Refs. } \\
\hline & & & Identification & Quantitation * \\
\hline \multicolumn{5}{|c|}{ Acids } \\
\hline 1 & 2-Hexenoic acid & $\mathrm{X}$ & {$[8,9]$} & \\
\hline 2 & 2-Methylbutanoic acid & $\operatorname{tr}$ & {$[10]$} & [11] \\
\hline 3 & 3-Hexenoic acid & $\mathrm{X}$ & {$[8,9]$} & \\
\hline 4 & $\begin{array}{l}\text { 3-Methylbutanoic acid } \\
\text { (isopentanoic acid) }\end{array}$ & 0.05 & {$[8,9]$} & {$[12]$} \\
\hline 5 & 3-Methyl-2-butenoic acid & $\operatorname{tr}$ & & [11] \\
\hline 6 & 3-Methyl-3-butenoic acid & $\operatorname{tr}$ & & [11] \\
\hline 7 & Acetic acid & $1.35 ; 16 ; 5.4-135 ; 0.0205-0.275$ & {$[8, \mathbf{1 0}, \mathbf{1 3}, \mathbf{1 4}]$} & {$[11,12,15,16]$} \\
\hline 8 & Benzoic acid & $<0.025 ; \operatorname{tr}$ & [9] & {$[11,12]$} \\
\hline 9 & Butanoic acid & $0.25 ; 0.6$ & {$[8,9, \mathbf{1 0}, \mathbf{1 5}]$} & {$[11,12]$} \\
\hline 10 & $\begin{array}{l}\text { 3-Phenylprop-2-enoic acid } \\
\text { (cinnamic acid) }\end{array}$ & $\mathrm{X}$ & [9] & \\
\hline 11 & Decanoic acid & $<0.025 ; \operatorname{tr}$ & [9] & {$[11,12]$} \\
\hline 12 & Dodecanoic acid & $\mathrm{X}$ & [9] & \\
\hline 13 & Ethylhexanoic acid & $\mathrm{X}$ & [9] & \\
\hline 14 & Formic acid & $\mathrm{X}$ & [8] & \\
\hline 15 & Heptanoic acid & 0.15 & [9] & [12] \\
\hline 16 & Hexadecanoic acid & $\operatorname{Tr}$ & & [11] \\
\hline 17 & $\begin{array}{l}\text { Hexanedioic acid } \\
\text { (adipic acid) }\end{array}$ & $\mathrm{X}$ & [9] & \\
\hline 18 & Hexanoic acid & $1.7 ; 6.7 ; 0.4-19.3 ; 0.0286-0.1586$ & {$[8,9, \mathbf{1 3}, \mathbf{1 4}]$} & {$[11,12,15,16]$} \\
\hline 19 & $\begin{array}{l}\text { 2-Methylpropanoic acid } \\
\text { (isobutanoic acid) }\end{array}$ & $<0.025$ & {$[8,9]$} & {$[12]$} \\
\hline 20 & $\begin{array}{l}\text { 4-Methylpentanoic acid } \\
\text { (isohexanoic acid) }\end{array}$ & $\mathrm{X}$ & [9] & \\
\hline 21 & Methyldodecanoic acid & $\mathrm{X}$ & [9] & \\
\hline 22 & Nonanedioic acid & $\mathrm{X}$ & [9] & \\
\hline 23 & Nonanoic acid & 0.05 & [9] & {$[12]$} \\
\hline 24 & Octanoic acid & $0.6 ; \operatorname{tr}$ & {$[8,9,15]$} & {$[11,12]$} \\
\hline 25 & Octenoic acid (unkn.str.) & $\mathrm{X}$ & [9] & \\
\hline 26 & Pentadecanoic acid & $\mathrm{X}$ & [9] & \\
\hline 27 & Pentadecen-1-oic acid & $\mathrm{X}$ & [9] & \\
\hline 28 & Pentadecen-3-oic acid & $\mathrm{X}$ & [9] & \\
\hline 29 & Pentadecenoic acid (branched) & $\mathrm{X}$ & [9] & \\
\hline 30 & Pentanoic acid & $<0.025$ & {$[8,9,15]$} & {$[12]$} \\
\hline 31 & Phenylacetic acid & $\mathrm{X}$ & {$[9,10]$} & \\
\hline 32 & Propanoic acid & $<0.025 ; \operatorname{tr}$ & {$[8,9]$} & {$[11,12]$} \\
\hline 33 & Tetradecanoic acid & $\operatorname{tr}$ & [9] & {$[11]$} \\
\hline 34 & Tetradecen-1-oic acid & $\mathrm{X}$ & [9] & \\
\hline 35 & Tetradecen-2-oic acid & $\mathrm{X}$ & [9] & \\
\hline 36 & Tetradecen-3-oic acid & $\mathrm{X}$ & [9] & \\
\hline 37 & Tridecanoic acid & $\mathrm{X}$ & [9] & \\
\hline 38 & Vinylbenzoic acid & $\mathrm{X}$ & [9] & \\
\hline
\end{tabular}


Table 1. Cont.

\begin{tabular}{|c|c|c|c|c|}
\hline & \multirow{2}{*}{ Compounds } & \multirow{2}{*}{$\begin{array}{c}\text { Quantitative Data } \\
\text { (mg/Kg) }\end{array}$} & \multicolumn{2}{|c|}{ Refs. } \\
\hline & & & Identification & Quantitation * \\
\hline \multicolumn{5}{|c|}{ Alcohols } \\
\hline 39 & (E)-2-Buten-1-ol & $<0.01$ & & [17] \\
\hline 40 & (E)-2-Hexen-1-ol & $\operatorname{tr}$ & & {$[11]$} \\
\hline 41 & (E)-3-Hexen-1-ol & 0.7 & & {$[11]$} \\
\hline 42 & $\begin{array}{l}\text { 2(E)-3-Phenylprop-2-en-1-ol } \\
((E) \text {-cinnamyl alcohol) }\end{array}$ & $\operatorname{tr}$ & {$[9,10]$} & {$[\mathbf{1 1}]$} \\
\hline 43 & (E)-Penten-2-ol & $<0.005$ & & {$[18]$} \\
\hline 44 & (Z)-3-Hexen-1-ol & $\begin{array}{c}0.1-1 ; 0.1 ; 7.0 ; 0.0091-0.0150,0.005-0.05 \\
\quad 0.06-0.47 ; 0.228-0.327 ; 0.145-0.249\end{array}$ & {$[9, \mathbf{1 0}, \mathbf{1 3}, \mathbf{1 4}, 19-21]$} & $\begin{array}{l}{[11,12,15,16,17,18,} \\
22,23]\end{array}$ \\
\hline 45 & (Z)-Octen-2-ol & $0.005-0.05$ & & {$[12]$} \\
\hline 46 & 1-Butanol & $0.05 ; 0.01-0.1$ & & {$[12,17]$} \\
\hline 47 & 1-Heptanol & $0.005-0.05$ & [9] & {$[\mathbf{1 8}]$} \\
\hline 48 & 1-Hexanol & $0.01-0.1 ; 1.4 ; 0.0008-0.0029 ; 0.005-0.05 ; 0.1 ;$ & {$[9,10, \mathbf{1 3}, 19-21]$} & {$[11,12,16,17,18]$} \\
\hline 49 & 1-Nonanol & $0.005-0.05$ & & {$[18]$} \\
\hline 50 & 1-Octanol & $0.005-0.05$ & {$[9, \mathbf{1 0}, \mathbf{1 3}]$} & {$[18]$} \\
\hline 51 & 1-Octen-3-ol & $\mathrm{X}$ & {$[10,13,16]$} & \\
\hline 52 & 1-Pentanol & $<0.01 ; 0.005-0.05 ; \operatorname{tr}$ & {$[9,15]$} & {$[11,17,18]$} \\
\hline 53 & 1-Penten-3-ol & $0.01-0.1$ & [9] & {$[17]$} \\
\hline 54 & 1-Phenyl-1-propanol & $\mathrm{X}$ & [9] & \\
\hline 55 & 1-Propanol & $<0.025$ & & {$[12]$} \\
\hline 56 & 2-Butanol & $\mathrm{X}$ & [19] & \\
\hline 57 & 2-Heptanol & $0.00073-0.00664$ & {$[9, \mathbf{1 3}]$} & {$[16]$} \\
\hline 58 & 2-Methylbutan-1-ol & $\operatorname{tr}$ & [19] & {$[\mathbf{1 1}]$} \\
\hline 59 & 2-Methylpropanol & $\operatorname{tr}$ & {$[15,19]$} & {$[11]$} \\
\hline 60 & 2-Nonanol & $0.002-0.012 ; 0.003-0.007$ & [10] & {$[22,23]$} \\
\hline 61 & 2-Phenylethanol & 0.5 & {$[9, \mathbf{1 0}, \mathbf{1 5}]$} & {$[11]$} \\
\hline 62 & 3-Methyl-2-Buten-1-ol & $0.1 ; 3.2$ & [9] & {$[11,12]$} \\
\hline 63 & 3-Methyl-3-Buten-1-ol & $0.01-0.1$ & & {$[17]$} \\
\hline 64 & 3-Methyl-3-Buten-2-ol & $0.01-0.1$ & & [17] \\
\hline 65 & 3-Methylbutan-1-ol & $<0.025 ; 0.05-0.5$ & {$[9,19]$} & {$[12,17]$} \\
\hline 66 & 3-Pentanol & $\mathrm{X}$ & [19] & \\
\hline 67 & $\begin{array}{l}\text { 4-Isopropylbenzyl alcohol } \\
\text { (cuminol) }\end{array}$ & $0.032-0.074 ; 0.023-0.064$ & & {$[22,23]$} \\
\hline 68 & 4-Methyl-1-pentanol & $\mathrm{X}$ & [9] & \\
\hline 69 & 6-Methyl-5-hepten-2-ol & $\mathrm{X}$ & {$[9,20]$} & \\
\hline 70 & Benzyl alcohol & $<0.005 ; 3.5 ; 0.08-0.55 ; 0.00765-0.02754 ; 0.6$ & {$[9,10, \mathbf{1 3}, \mathbf{1 4}]$} & {$[11,12,15,16,18]$} \\
\hline 71 & Ethanol & $0.01-0.1 ; \operatorname{tr} ; 0.55$ & {$[19,24,25]$} & {$[11,12,17]$} \\
\hline 72 & Methanol & $<0.01$ & {$[19,24,25]$} & {$[17]$} \\
\hline \multicolumn{5}{|c|}{ Phenols } \\
\hline 73 & $\begin{array}{l}\text { 2-Methoxy-4-vinylphenol } \\
\text { (4-vinylguaiacol) }\end{array}$ & $\operatorname{tr}$ & & {$[11]$} \\
\hline 74 & 2-Methoxy-5-vinylphenol & $\operatorname{tr}$ & & {$[\mathbf{1 1}]$} \\
\hline 75 & 4-Vinylphenol & 0.3 & & {$[11]$} \\
\hline
\end{tabular}


Table 1. Cont.

\begin{tabular}{|c|c|c|c|c|}
\hline & \multirow{2}{*}{ Compounds } & \multirow{2}{*}{$\begin{array}{c}\text { Quantitative Data } \\
\text { (mg/Kg) }\end{array}$} & \multicolumn{2}{|c|}{ Refs. } \\
\hline & & & Identification & Quantitation * \\
\hline \multicolumn{5}{|c|}{ Aldehydes } \\
\hline 76 & (E)-2-Hexenal & $\begin{array}{c}0.1-1 ; 0-0.0077 ; \mathrm{tr} ; 0.260-0.357 \\
\quad 0.289-0.425 ; 0.005-0.05\end{array}$ & {$[10,13,15]$} & {$[11, \mathbf{1 6}, \mathbf{1 8}, \mathbf{2 2}, \mathbf{2 3}, 26]$} \\
\hline 77 & (Z)-3-Hexenal & $2 ; 0.005-0.05$ & [10] & {$[13,18]$} \\
\hline 78 & 2-Heptanal & $\mathrm{X}$ & [20] & \\
\hline 79 & 2-Methylbutanal & $\mathrm{X}$ & [19] & \\
\hline 80 & 2-Methylpropanal & $\mathrm{X}$ & [19] & \\
\hline 81 & 2-Pentenal & $0.01-0.1$ & & {$[26]$} \\
\hline 82 & 3-Methyl-2-butenal & $0.01-0.1$ & & [26] \\
\hline 83 & 3-Methylbutanal & $\mathrm{X}$ & [19] & \\
\hline 84 & $\begin{array}{l}\text { 3-Pyridinecarboxaldehyde } \\
\text { (nicotinaldehyde) }\end{array}$ & $\mathrm{X}$ & [19] & \\
\hline 85 & $\begin{array}{l}\text { 5-(Hydroxymethyl)-2-furaldehyde } \\
\text { (hydroxymethylfurfural) }\end{array}$ & $0.00143-0.00231$ & & {$[16]$} \\
\hline 86 & 5-Methylfurfural & $\mathrm{X}$ & {$[16]$} & \\
\hline 87 & $\begin{array}{l}\text { Acetaldehyde } \\
\text { (ethanal) }\end{array}$ & 26 & {$[19,24,25]$} & {$[26]$} \\
\hline 88 & Benzaldehyde & $0.2 ; 0.00165-0.00246$ & {$[9,10, \mathbf{1 3}, 19]$} & {$[11,16]$} \\
\hline 89 & Decanal & $0-0.00068$ & {$[9, \mathbf{1 3}, 19]$} & {$[16]$} \\
\hline 90 & Heptanal & $\mathrm{X}$ & {$[9,10,19]$} & \\
\hline 91 & Hexanal & $\begin{array}{c}0.1-1 ; 0.00487-0.0109 ; \text { tr; } 0.027-0.066 ; \\
0.090-0.172 ; 0.005-0.05\end{array}$ & {$[9, \mathbf{1 0}, \mathbf{1 3}, \mathbf{1 5}, 19]$} & {$[11,16,18,22,23,26]$} \\
\hline 92 & Nonanal & $\mathrm{X}$ & {$[9, \mathbf{1 0}, 19,21]$} & \\
\hline 93 & Octanal & $\mathrm{X}$ & [8] & \\
\hline 94 & Pentanal & $\mathrm{X}$ & [8] & \\
\hline 95 & Propanal & $<0.01$ & & {$[13]$} \\
\hline 96 & Propenal & $<0.01$ & & {$[13]$} \\
\hline 97 & Undecanal & $\mathrm{X}$ & [9] & \\
\hline \multicolumn{5}{|c|}{ Ketones } \\
\hline 98 & (Z)-Jasmone & $\mathrm{X}$ & [9] & \\
\hline 99 & 1-Octen-3-one & $\mathrm{X}$ & {$[10]$} & \\
\hline 100 & $\begin{array}{l}\text { 2,3-Butanedione } \\
\text { (diacetyl) }\end{array}$ & $0.05 ;<0.01$ & {$[10]$} & {$[12,26]$} \\
\hline 101 & 2-Butanone & $\mathrm{X}$ & {$[9,19]$} & \\
\hline 102 & 2-Decanone & $\mathrm{X}$ & {$[9,20]$} & \\
\hline 103 & 2-Heptanone & $0.061-0.102 ; 0.063-0.108$ & {$[9,10, \mathbf{1 3}, \mathbf{1 6}, 21]$} & \\
\hline 104 & 2-Hexanone & $\mathrm{X}$ & [9] & \\
\hline 105 & 2-Nonanone & $0.005-0.05 ; 0.011-0.034 ; 0.020-0.036$ & {$[9,10,20,21]$} & {$[18,22,23]$} \\
\hline 106 & 2-Octanone & $\mathrm{X}$ & [9] & {$[13]$} \\
\hline 107 & 2-Pentanone & $<0.01$ & [9] & \\
\hline 108 & 2-Tridecanone & $\mathrm{X}$ & [9] & \\
\hline 109 & 2-Undecanone & $\mathrm{X}$ & {$[9, \mathbf{1 0}]$} & \\
\hline 110 & 3-Methyl-2-butanone & $\mathrm{X}$ & [19] & \\
\hline 111 & 3-Methyl-2-heptanone & $\mathrm{X}$ & [19] & \\
\hline 112 & 3-Pentanone & $\mathrm{X}$ & [19] & \\
\hline
\end{tabular}


Table 1. Cont.

\begin{tabular}{|c|c|c|c|c|}
\hline & \multirow{2}{*}{ Compounds } & \multirow{2}{*}{$\begin{array}{c}\text { Quantitative Data } \\
\text { (mg/Kg) }\end{array}$} & \multicolumn{2}{|c|}{ Refs. } \\
\hline & & & Identification & Quantitation * \\
\hline \multicolumn{5}{|c|}{ Ketones } \\
\hline 113 & $\begin{array}{l}\text { 4-Phenyl-2-butanone } \\
\text { (benzylacetone) }\end{array}$ & $\mathrm{X}$ & [9] & \\
\hline 114 & 6-Methyl-5-hepten-2-one & 3.2 & {$[9,19]$} & [11] \\
\hline 115 & $\begin{array}{l}\text { 3-Hydroxybutanone } \\
\text { (acetoin) }\end{array}$ & $0.1-1 ; 3.6 ; 0.125-0.749 ; 0.15 ; 0.005-0.05$ & {$[9, \mathbf{1 3}, \mathbf{1 4}, 19]$} & {$[11,12,16,18,26]$} \\
\hline 116 & $\begin{array}{l}\text { Propan-2-one } \\
\text { (acetone) }\end{array}$ & $0.01-0.1$ & {$[15,19]$} & [26] \\
\hline 117 & Acetophenone & $0.00037-0.00192 ; 0.005-0.05$ & {$[13]$} & {$[16,18]$} \\
\hline \multicolumn{5}{|c|}{ Lactones } \\
\hline 118 & $\begin{array}{l}\text { 2-Hexen-4-olide } \\
\text { (5-ethyl-5H-furan-2-one) }\end{array}$ & $0.005-0.05$ & & {$[18]$} \\
\hline 119 & $\begin{array}{l}\text { Sotolon } \\
\text { (sugar lactone) }\end{array}$ & $\mathrm{X}$ & [10] & \\
\hline 120 & 5-Ethyl-( $3 H)$-furan-2-one & $\mathrm{X}$ & [13] & \\
\hline 121 & $\begin{array}{l}\text { 5-Ethyl-3-hydroxy-4-methyl-5H-furan- } \\
\text { 2-one (maple furanone) }\end{array}$ & $\mathrm{X}$ & [10] & \\
\hline 122 & $\begin{array}{l}\gamma \text {-Butyrolactone } \\
\text { (dihydrofuran-2(3H)-one) }\end{array}$ & $\mathrm{X}$ & {$[9,20]$} & \\
\hline 123 & $\begin{array}{l}\gamma \text {-Hexalactone } \\
\text { (4-hydroxyhexanoic acid lactone) }\end{array}$ & $0.005-0.05 ; 0.7 ; 0.05$ & {$[9,10,20]$} & {$[11,12,18]$} \\
\hline 124 & $\begin{array}{l}\gamma \text {-Octalactone } \\
\text { (4-hydroxyoctanoic acid lactone) }\end{array}$ & $<0.005 ; 0.4 ; 0.05$ & [9] & {$[11,12,18]$} \\
\hline 125 & $\delta$-Decalactone & $\begin{array}{c}0.005-0.05 ; 0.01379-0.06106 ; 1 ; 0.666-0.917 ; \\
0.476-0.625\end{array}$ & {$[9,10, \mathbf{1 3}, 20]$} & {$[11,16,18,22,23]$} \\
\hline 126 & $\delta$-Dodecalactone & 0.2 & [9] & [11] \\
\hline 127 & $\delta$-Hexalactone & 0.6 & [9] & {$[11]$} \\
\hline 128 & $\delta$-Octalactone & 0.7 & {$[9,10]$} & {$[11,22,23]$} \\
\hline \multicolumn{5}{|c|}{ Furans } \\
\hline 129 & $\begin{array}{l}\text { 2,5-Dimethyl-4-hydroxy-3( } 2 H) \text { furanone } \\
\text { (strawberry ketone) }\end{array}$ & 0.1 & {$[10]$} & {$[\mathbf{1 1}]$} \\
\hline 130 & $\begin{array}{l}\text { 2,5-Dimethyl-4-methoxy-3(2H) furanone } \\
\text { (berry furanone) }\end{array}$ & $\operatorname{tr}$ & & {$[\mathbf{1 1}]$} \\
\hline 131 & $\begin{array}{l}\text { 2-Ethyl-4-hydroxy-5-methyl-3-( } 2 H) \text { - } \\
\text { furanone (homofuraneol) }\end{array}$ & $\mathrm{X}$ & [10] & \\
\hline 132 & 2-Ethylfuran & $\mathrm{X}$ & [19] & \\
\hline 133 & 2-Pentylfuran & $\mathrm{X}$ & [19] & \\
\hline 134 & $\begin{array}{l}\text { 5-Methyl-4-hydroxy-3(2H) furanone } \\
\text { (norfuraneol) }\end{array}$ & 0.1 & & {$[11]$} \\
\hline 135 & $\begin{array}{l}\text { Dihydroactinidiolide } \\
\text { (apricot furanone) }\end{array}$ & $\mathrm{X}$ & [21] & \\
\hline
\end{tabular}


Table 1. Cont.

\begin{tabular}{|c|c|c|c|c|}
\hline & \multirow{2}{*}{ Compounds } & \multirow{2}{*}{$\begin{array}{c}\text { Quantitative Data } \\
\text { (mg/Kg) }\end{array}$} & \multicolumn{2}{|c|}{ Refs. } \\
\hline & & & Identification & Quantitation * \\
\hline \multicolumn{5}{|c|}{ Esters } \\
\hline 136 & (Z)-3-Hexenyl acetate & $\operatorname{tr} ; 0.004-0.01 ; 0.003-0.011$ & {$[9,10, \mathbf{1 3}, 19,21]$} & {$[11,22,23]$} \\
\hline 137 & (Z)-3-Hexenyl formate & $\operatorname{tr}$ & & [11] \\
\hline 138 & 2-Methylbutyl acetate & $\mathrm{X}$ & [9] & \\
\hline 139 & 3-Hexen-1-yl-acetate (unkn str.) & $<0.005$ & [20] & {$[18]$} \\
\hline 140 & 3-Methyl-2-buten-1-yl acetate & $\operatorname{tr}$ & & {$[11]$} \\
\hline 141 & 3-Methyl-2-buten-1-yl formate & $\operatorname{tr}$ & & {$[\mathbf{1 1}]$} \\
\hline 142 & $\begin{array}{l}\text { 3-Methylbutyl acetate } \\
\text { (isoamyl acetate) }\end{array}$ & $\mathrm{X}$ & {$[9,10,20]$} & \\
\hline 143 & Benzyl acetate & $\operatorname{tr}$ & & [11] \\
\hline 144 & Butyl acetate & $\mathrm{X}$ & {$[10]$} & \\
\hline 145 & Ethyl 2-butenoate & $\mathrm{X}$ & [10] & \\
\hline 146 & Ethyl 2-methylbutanoate & $\mathrm{X}$ & {$[10]$} & \\
\hline 147 & Ethyl 2-methylpropanoate & $\mathrm{X}$ & {$[10]$} & \\
\hline 148 & Ethyl 3-methylbutanoate & $\mathrm{X}$ & {$[10]$} & \\
\hline 149 & Ethyl 2-phenylacetate & $\mathrm{X}$ & {$[16]$} & \\
\hline 150 & Ethyl 5-hydroxydecanoate & 0.8 & & [11] \\
\hline 151 & Ethyl 5-hydroxyoctanoate & 1.3 & & [11] \\
\hline 152 & Ethyl acetate & $\operatorname{tr}$ & {$[8, \mathbf{1 0}, \mathbf{1 3}, 19]$} & {$[\mathbf{1 1}]$} \\
\hline 153 & Ethyl benzoate & $\mathrm{X}$ & [10] & \\
\hline 154 & Ethyl butanoate & $\mathrm{X}$ & {$[\mathbf{1 0}]$} & \\
\hline 155 & Ethyl hexanoate & $0.005-0.013 ; 0.005-0.011$ & {$[9, \mathbf{1 0}]$} & {$[22,23]$} \\
\hline 156 & Ethyl octanoate & $\mathrm{X}$ & [10] & \\
\hline 157 & Ethyl propanoate & $\mathrm{X}$ & {$[10]$} & \\
\hline 158 & Hexyl acetate & $\mathrm{X}$ & {$[9, \mathbf{1 3}, \mathbf{1 5}, \mathbf{1 6}, 20]$} & \\
\hline 159 & Hexyl fomate & $\mathrm{X}$ & [10] & \\
\hline 160 & Methyl 2-hydroxybenzoate & $\mathrm{X}$ & [19] & \\
\hline 161 & Methyl acetate & $\mathrm{X}$ & {$[9,19]$} & \\
\hline 162 & Methyl hexanoate & $\mathrm{X}$ & {$[9, \mathbf{1 0}]$} & \\
\hline 163 & Methyl jasmonate & $\mathrm{X}$ & {$[16]$} & \\
\hline 164 & Methyl nicotinate & $\mathrm{X}$ & [19] & \\
\hline 165 & Methyl nonanoate & $0-0.001 ; 0-0.001$ & & {$[22,23]$} \\
\hline 166 & Pentenyl acetate & $\mathrm{X}$ & [20] & \\
\hline 167 & Propyl acetate & $\mathrm{X}$ & [10] & \\
\hline \multicolumn{5}{|c|}{ Ether } \\
\hline 168 & Methoxybenzene & $\mathrm{X}$ & [19] & \\
\hline \multicolumn{5}{|c|}{ Hydrocarbons } \\
\hline 169 & (E)-3-Methyl-1,3,5-hexatriene & $\mathrm{X}$ & [13] & \\
\hline 170 & 2-Methylbutane & $\mathrm{X}$ & [19] & \\
\hline 171 & 2-Methylnaphthalene & $0.005-0.05$ & [9] & {$[18]$} \\
\hline 172 & 2-Methylpentane & $\mathrm{X}$ & [19] & \\
\hline 173 & 3-Methyl-1,3-pentadiene & $\mathrm{X}$ & [19] & \\
\hline 174 & Acenaphtene & $<0.005$ & & {$[18]$} \\
\hline 175 & Decane & $X$ & [19] & \\
\hline
\end{tabular}


Table 1. Cont.

\begin{tabular}{|c|c|c|c|c|}
\hline & \multirow{2}{*}{ Compounds } & \multirow{2}{*}{$\begin{array}{c}\text { Quantitative Data } \\
(\mathbf{m g} / \mathbf{K g})\end{array}$} & \multicolumn{2}{|c|}{ Refs. } \\
\hline & & & Identification & Quantitation * \\
\hline \multicolumn{5}{|c|}{ Hydrocarbons } \\
\hline 176 & Dimethylbenzene (xylene) & $\operatorname{tr}$ & {$[9,21]$} & {$[\mathbf{1 1}]$} \\
\hline 177 & Dodecane & $\mathrm{X}$ & [19] & \\
\hline 178 & Naphtalene & $<0.005$ & [9] & {$[\mathbf{1 8}]$} \\
\hline 179 & Nonane & $\mathrm{X}$ & [19] & \\
\hline 180 & Octane & $\mathrm{X}$ & [19] & \\
\hline 181 & Pentadecane & $\mathrm{X}$ & [19] & \\
\hline 182 & Pentane & $\mathrm{X}$ & [19] & \\
\hline 183 & Tetradecane & $\mathrm{X}$ & [19] & \\
\hline 184 & Tridecane & $\mathrm{X}$ & [19] & \\
\hline 185 & Undecane & $\mathrm{X}$ & [19] & \\
\hline \multicolumn{5}{|c|}{ Monoterpenes } \\
\hline 186 & (E)-4,8-Dimethyl-1,3,7-nonatriene & $\mathrm{X}$ & [19] & \\
\hline 187 & (E)-Linalool oxide (furan) & $\mathrm{X}$ & [9] & \\
\hline 188 & (E)-Linalool oxide (pyran) & $\mathrm{X}$ & [9] & \\
\hline 189 & $(E)$ - $\beta$-Ocimene & $\mathrm{X}$ & {$[10,19]$} & \\
\hline 190 & (Z)-4,8-Dimethyl-1,3,7-nonatriene & $\mathrm{X}$ & [19] & \\
\hline 191 & (Z)-Linalool oxide (furan) & $\mathrm{X}$ & [9] & \\
\hline 192 & (Z)-Linalool oxide (pyran) & $\mathrm{X}$ & [9] & \\
\hline 193 & (Z)-Piperitol & $\mathrm{X}$ & [9] & \\
\hline 194 & (Z)-Sabinol & 0.2 & & [11] \\
\hline 195 & $(Z)-\beta$-Ocimene & $\mathrm{X}$ & [19] & \\
\hline 196 & 1,8-Cineole(eucalyptol) & $\mathrm{X}$ & [9] & \\
\hline 197 & 3-Methyl raspberry ketone & $\mathrm{X}$ & [9] & \\
\hline 198 & Terpinen-4-ol & $\begin{array}{c}0.05-0.5 ; \\
0-0.00644 ; 0.5 ; 0.100-0.201 ; 0.096-0.172\end{array}$ & {$[9, \mathbf{1 3}, \mathbf{1 5}, 20,21]$} & {$[11,16,18,22,23]$} \\
\hline 199 & Cadinene & $\mathrm{x}$ & [19] & \\
\hline 200 & Camphene & & {$[9,19,20]$} & \\
\hline 201 & Camphor & $0.005-0.05$ & & {$[\mathbf{1 8}]$} \\
\hline 202 & Cyclocitral & $\mathrm{x}$ & [9] & \\
\hline 203 & Dihydroactinidiolide & $\mathrm{x}$ & [9] & \\
\hline 204 & Dihydrolinalool & $\mathrm{x}$ & [9] & \\
\hline 205 & Eugenol & $\operatorname{tr}$ & {$[10]$} & [11] \\
\hline 206 & Geranial & $0.005-0.05$ & {$[9,20]$} & {$[\mathbf{1 8}]$} \\
\hline 207 & Geraniol & $\begin{array}{c}0.1-1 ; 0.5 ; 0.05-0.5 ; 0.16-1.93 ; 0.15 ; \\
0.102-0.172 ; 0.121-0.167 ; 0.00209-0.00778\end{array}$ & {$[9,10, \mathbf{1 3}, \mathbf{1 4}, 20,21]$} & $\begin{array}{l}{[11-13,} \\
15,18,22,23,26]\end{array}$ \\
\hline 208 & Isopiperitenone & $\mathrm{X}$ & [9] & \\
\hline 209 & Limonene & $\operatorname{tr} ; 0.001-0.002 ; 0.002$ & {$[10,13,19]$} & {$[11,22,23]$} \\
\hline 210 & Linalool & $\begin{array}{c}0.005-0.05 ; 0.8 ; 0.01-0.92 ; 0.00124-0.01126 \\
0.15 ; 0.031-0.044 ; 0.008-0.015\end{array}$ & $\begin{array}{l}{[\mathbf{1 0}, \mathbf{1 3}, \mathbf{1 4}, 17,20,} \\
21]\end{array}$ & $\begin{array}{l}{[11,12,15,16,18,22,} \\
23]\end{array}$ \\
\hline 211 & Linalool oxides & $\operatorname{tr}$ & & {$[\mathbf{1 1}]$} \\
\hline 212 & Linalyl acetate & $\mathrm{X}$ & [10] & \\
\hline 213 & Menthene & $\mathrm{X}$ & [9] & \\
\hline 214 & Menthol & $\operatorname{tr}$ & & [11] \\
\hline 215 & Menthyl acetate & $\mathrm{X}$ & {$[9,20]$} & \\
\hline
\end{tabular}


Table 1. Cont.

\begin{tabular}{|c|c|c|c|c|}
\hline & \multirow{2}{*}{ Compounds } & \multirow{2}{*}{$\begin{array}{c}\text { Quantitative Data } \\
\text { (mg/Kg) }\end{array}$} & \multicolumn{2}{|c|}{ Refs. } \\
\hline & & & Identification & Quantitation * \\
\hline \multicolumn{5}{|c|}{ Monoterpenes } \\
\hline 216 & Myrtenol & $0.00007-0.00133$ & [9] & {$[16]$} \\
\hline 217 & neo-Allo-ocimene & $\mathrm{X}$ & [10] & \\
\hline 218 & Neral & $<0.005$ & {$[9,20]$} & {$[\mathbf{1 8}]$} \\
\hline 219 & Nerol & $0.005-0.05 ; 0.5 ; 0.019-0.037 ; 0.015-0.027$ & {$[9,20,21]$} & {$[11,18,22,23]$} \\
\hline 220 & $\begin{array}{l}p \text {-Cymene } \\
\text { (1-isopropyl-4-methylbenzene) }\end{array}$ & $\begin{array}{c}0.9 ; 0.00011-0.00034 ; 0.008-0.023 ; \\
0.012-0.024\end{array}$ & {$[9, \mathbf{1 3}, 20,21]$} & {$[11,16,22,23]$} \\
\hline 221 & $p$-Cymene-8-ol & $\mathrm{X}$ & {$[9,20]$} & \\
\hline 222 & Piperitone & $0.005-0.05 ; 0.2$ & [9] & {$[11,18]$} \\
\hline 223 & $p$-Menthen-2-ol & $0.005-0.05$ & & {$[\mathbf{1 8}]$} \\
\hline 224 & $\begin{array}{l}\text { Raspberry ketone } \\
\text { (4-(4-Hhydroxyphenyl)butan-2-one) }\end{array}$ & $3.1 ; 1.09-4.20$ & {$[9,10, \mathbf{1 4}]$} & {$[11,15]$} \\
\hline 225 & $\begin{array}{l}\text { Sabinene } \\
\text { (thuj-4(10)-ene) }\end{array}$ & $\operatorname{tr} ; 0.013-0.032 ; 0.015-0.030$ & [10] & {$[11,22,23]$} \\
\hline 226 & Terpinolene & $0.7 ; 0.001-0.004$ & {$[9,20]$} & {$[11,22]$} \\
\hline 227 & Vanillin & $\operatorname{tr}$ & [10] & {$[\mathbf{1 1}]$} \\
\hline 228 & $\begin{array}{l}\text { 3,4-Dimethoxybenzaldehyde } \\
\text { (methylvanillin) }\end{array}$ & $\operatorname{tr}$ & & {$[\mathbf{1 1}]$} \\
\hline 229 & $\begin{array}{l}\text { 4-Methoxybenzaldehyde } \\
\text { (p-anisaldehyde) }\end{array}$ & $\mathrm{X}$ & [19] & \\
\hline 230 & Verbenone & $\mathrm{X}$ & [9] & \\
\hline 231 & Zingerone & $0.3 ; 0.059-0.234$ & [10] & {$[11,22]$} \\
\hline 232 & $\alpha$-Cyclogeranyl acetate & $\mathrm{X}$ & [13] & \\
\hline 233 & $\alpha$-Phellandrene & $\operatorname{tr} ; 0-0.0002 ; 0.026-0.100 ; 0.028-0.057$ & {$[9,10, \mathbf{1 3}, 20,21]$} & {$[11,16,22,23]$} \\
\hline 234 & $\alpha$-Pinene & $\operatorname{tr} ; 0.011-0.027 ; 0.025-0.033$ & $\begin{array}{l}{[9,10, \mathbf{1 3}, \mathbf{1 6}, 19,21,} \\
22]\end{array}$ & {$[11,22,23]$} \\
\hline 235 & $\alpha$-Terpinene & $0.011-0.027 ; 0.004-0.025$ & & {$[22,23]$} \\
\hline 236 & $\alpha$-Terpineol & $0.7 ; 0.012-0.022 ; 0.035-0.058$ & {$[9,10,20]$} & {$[11,16,22,23]$} \\
\hline 237 & $\beta$-Myrcene & $0.001-0.008 ; 0.004-0.006$ & {$[9,10, \mathbf{1 3}, 19-21]$} & {$[22,23]$} \\
\hline 238 & $\beta$-Phellandrene & $\mathrm{X}$ & {$[9,13,20,21]$} & \\
\hline 239 & $\beta$-Pinene & $0-0.0005$ & {$[9,10,13,20,21]$} & {$[16]$} \\
\hline 240 & $\gamma$-Terpinene & $0-0.018 ; 0-0.00016 ; 0.008-0.025$ & {$[9,10, \mathbf{1 3}, 20,21]$} & {$[16,22,23]$} \\
\hline 241 & $\delta$-3-Carene & $\mathrm{X}$ & [19] & \\
\hline \multicolumn{5}{|c|}{ Sesquiterpenes } \\
\hline 242 & (E)- $\alpha$-Bergamotene & $\mathrm{X}$ & [10] & \\
\hline 243 & (E)- $\beta$-Caryophyllene & $0.15 ; 1.2$ & {$[9, \mathbf{1 3}, \mathbf{1 6}, 19,20]$} & {$[11,12]$} \\
\hline 244 & Caryophyllene oxide & $0-0.00933$ & {$[13]$} & {$[16]$} \\
\hline 245 & Humulene & $\operatorname{tr}$ & [9] & [11] \\
\hline 246 & $\alpha$-Caryophyllene & $\mathrm{X}$ & [19] & \\
\hline 247 & $\alpha$-Copaene & $\mathrm{X}$ & [19] & \\
\hline 248 & $\alpha$-Elemene & 0.1 & & [11] \\
\hline 249 & $\alpha$-Farnesene & $\mathrm{X}$ & [19] & \\
\hline 250 & $\alpha$-Muurolene & $\mathrm{X}$ & [19] & \\
\hline 251 & $\beta$-Bourbonene & $\mathrm{X}$ & [19] & \\
\hline 252 & $\beta$-Cubenene & $\mathrm{X}$ & [19] & \\
\hline
\end{tabular}


Table 1. Cont.

\begin{tabular}{|c|c|c|c|c|}
\hline & \multirow{2}{*}{ Compounds } & \multirow{2}{*}{$\begin{array}{c}\text { Quantitative Data } \\
\text { (mg/Kg) }\end{array}$} & \multicolumn{2}{|c|}{ Refs. } \\
\hline & & & Identification & Quantitation * \\
\hline \multicolumn{5}{|c|}{ C13-norisoprenoids } \\
\hline 253 & (E)- $\beta$-ionone-5,6-epoxide & $\mathrm{X}$ & [13] & \\
\hline 254 & 3,4-Didehydro- $\beta$-ionone & $\mathrm{X}$ & [13] & \\
\hline 255 & 4-Oxo- $\beta$-ionone & $\mathrm{X}$ & [10] & \\
\hline 256 & Cyclo-ionone I/edulan & $\mathrm{X}$ & [13] & \\
\hline 257 & Dehydro- $\beta$-ionone & $\mathrm{X}$ & {$[13,21]$} & \\
\hline 258 & Dihydro $\beta$-ionol & $\mathrm{X}$ & {$[10,13]$} & \\
\hline 259 & Dihydro- $\alpha$-ionone & $\mathrm{X}$ & {$[9,20]$} & \\
\hline 260 & Dihydro- $\beta$-ionone & $0.1 ;<0.005$ & {$[9,10,20]$} & {$[12,18]$} \\
\hline 261 & Epoxy- $\beta$-ionone & $0.005-0.05$ & & {$[18]$} \\
\hline 262 & Theaspirane (unkn str.) & $0.005-0.05$ & & {$[18]$} \\
\hline 263 & Theaspirane A & $0.00006-0.00035$ & & {$[16]$} \\
\hline 264 & Theaspirane B & $0-0.00037$ & {$[13,20]$} & {$[16]$} \\
\hline 265 & Theaspirane I & $\mathrm{X}$ & {$[9,21]$} & \\
\hline 266 & Theaspirane II & $\mathrm{X}$ & {$[9,21]$} & \\
\hline 267 & $\alpha$-Ionol & $0.00093-0.00811$ & {$[10, \mathbf{1 3}, \mathbf{1 4}]$} & {$[16]$} \\
\hline 268 & $\alpha$-Ionone & $\begin{array}{c}0.1-1 ; 0.4 ; 0.05-0.5 ; 0.72-1.81 \\
0.00869-0.01848 ; 0.95 \\
0.023-0.052 ; 0.053-0.089\end{array}$ & {$[9,10, \mathbf{1 3}, \mathbf{1 4}, 20,21]$} & $\begin{array}{l}{[11-13,} \\
15,16,18,22,23]\end{array}$ \\
\hline 269 & $\beta$-Damascenone & $<0.005$ & {$[9, \mathbf{1 0}, \mathbf{1 3}, \mathbf{1 4}]$} & {$[18]$} \\
\hline 270 & $\beta$-Ionone & $\begin{array}{c}<0.01 ; 0.5 ; 0.05-0.5 ; 0.55-2.32 \\
0.00858-0.03146 ; 0.9 \\
0.056-0.093 ; 0.073-0.094\end{array}$ & {$[9, \mathbf{1 0}, \mathbf{1 3}, \mathbf{1 4}, 20,21]$} & $\begin{array}{l}{[11-13,} \\
15,16,18,22,23]\end{array}$ \\
\hline 271 & $\beta$-Ionol & $0.00018-0.00595$ & & {$[16]$} \\
\hline \multicolumn{5}{|c|}{ Sulfur } \\
\hline 272 & 2-Methylthiophene & $\mathrm{X}$ & [10] & \\
\hline 273 & Dimethyl disulfide & $\mathrm{X}$ & {$[10]$} & \\
\hline 274 & Dimethyl sulfoxide & $\mathrm{X}$ & [27] & \\
\hline 275 & Dimethyl sulfone & $\mathrm{X}$ & [27] & \\
\hline 276 & Dimethyl sulfide & $\mathrm{X}$ & {$[10,24]$} & \\
\hline 277 & Methional & $\mathrm{X}$ & {$[\mathbf{1 0}]$} & \\
\hline 278 & Thiophene & $\mathrm{X}$ & [10] & \\
\hline \multicolumn{5}{|c|}{ Amine } \\
\hline 279 & N-Methylene-ethanamine & $\mathrm{X}$ & [19] & \\
\hline
\end{tabular}

* Concentrations obtained through: direct analysis of distilled fraction from mashed fruit [26]; solvent extraction of oil from distillation of mashed fruit $[12,17,18]$; solvent extraction of mashed fruit $[11,15,16]$; SBSE of aqueous fraction from mashed fruit [22,23]. References in which identity of compound has been confirmed by comparison with authentic standard are reported in bold. "X" refers to identified but not quantified compounds. "tr" stands for compound quantities reported as "trace amount".

\section{Volatile Compounds in Raspberry}

Raspberry volatiles are important for the perception of sensory quality (odor, flavor) and for mold resistance [13], and some are claimed to have nutraceutical properties [28,29], although the nutritional role of volatile compounds is still very controversial. Fruit volatile compounds are influenced by 
numerous factors including cultivar variation, climate, soil, ripeness, and many other variables [11,19,30]. Early studies focused on isolation and identification of these volatile compounds in particular those most likely related to raspberry aroma, later moving attention to the factors affecting volatile composition and their possible biological roles.

Since terms such as aroma and flavor are extensively used in the literature reviewed, sometimes to indicate volatile compounds in general, before we begin we would like to draw attention to the significance of these terms.

The term "aroma" refers to an odor, or to a compound responsible of an odor, with a pleasant or unpleasant connotation [31]. Odor is a sensation perceived by the olfactory receptors in sniffing certain volatile substances (ortho-nasal route).

The term "flavor" refers to "a perception resulting from stimulating a combination of the taste buds, the olfactory organs, and chemesthetic receptors within the oral cavity" [32], in other words it is the combination of taste and smell features (through the retro-nasal route).

The volatile compounds released by raspberry are free forms of different metabolites, most of them often in the form of glycoside bound to sugars. The presence of glycosidically-bound volatile compounds in plants is well established [33]; they are able to release free volatile compounds by enzymatic or chemical cleavage during plant maturation, industrial pretreatments or processing and may be considered potential aroma precursors [34].

\subsection{Free Forms}

Between the 1957 and 1971 researchers at Firmenich published a series of studies describing the isolation, fractionation and identification of volatile compounds in raspberry [8,17,18,26,35-38] (see Table 1). In these studies, the product derived from juice or purée distillation of fresh fruits was extracted using an organic solvent (pentane or benzene), concentrated to obtain the raspberry oil [26,35] and further extracted with ether, then each fraction (aqueous distillate, neutral ether extract and acid ether extract) was analyzed separately. Fourteen carbonyl compounds were isolated from the aqueous distillate using 2,4-dinitrophenylhydrazine reaction and separated by paper chromatography. The compounds were identified by infrared spectroscopy: diacetyl, acetoin, acetaldehyde, 2-propenal, acetone, propanal, 3-methylbut-2-enal, 2-pentenal, (Z)-3-hexenal, 2-hexenal, 2-pentanone, hexanal, $\alpha$-ionone and $\beta$-ionone [26]. Eleven alcohols were isolated from the ether extract of the distillate, separated by paper and column gas-chromatography, and identified by IR spectroscopy: 3-penten-1-ol, geraniol, (Z)-3-hexen-1-ol, hexan-1-ol, 3-methyl-3-buten-1-ol, 3-methyl-2-buten-1-ol, pentan-1-ol, butan-1-ol, (E)-2-buten-1-ol, ethanol, methanol [17]. The paper and column gas-chromatography (polar phase: Carbowax 20M) of the acidic fraction of raspberry oil allowed the separation of 11 acids and an ester, which were then identified by means of IR spectra: formic, acetic, hexanoic, octanoic, propanoic, butanoic, iso-butanoic, pentanoic, iso-pentanoic, 2-hexenoic, 3-hexenoic acids and ethyl acetate [8]. Finally, a further 39 compounds were identified in the neural fraction by GC-MS using columns with polar stationary phases (Chromosorb W and Carbowax 20M) and IR spectra [18] (Table 1).

Pyysalo compared the volatile compounds of a cultivated raspberry (Rubus idaeus cv. Ottawa) with a hybrid obtained by crossing raspberry (Rubus idaeus, L.) with arctic bramble (Rubus arcticus, L.) [12]. The volatile compounds were isolated from the press juice of the berries in a continuous vacuum 
evaporator, and separation, identification and quantification were than performed in three stages. The carbonyl compounds were determined as 2,4-dinitrophenylhydrazones, while the volatile acids and the neutral components were determined separately in a combined gas chromatograph-mass spectrometer using glass capillary columns coated with a polar phase (FFAP) [12]. More than 70 compounds were reported in the volatile fraction of the hybrid and 30 in the cultivated raspberry (the latter are reported in Table 1): identification was carried out from the recorded MS spectra.

Honkanen and collaborators obtained an extract containing neutral components and free fatty acids from press extracted berry juice of wild and cultivated (Rubus idaeus cv. Ottawa, Preussen) raspberries [11] using a pentane/ethyl ether extraction. A total of 75 volatile compounds were identified and quantified by GC-MS systems equipped with polar capillary columns coated with FFAP (Table 1). Compound identification was achieved by comparing the acquired MS spectra with those of the reference compounds.

A few years later, Guichard isolated volatile compounds in frozen raspberry (Rubus idaeus cv. Lloyd George) using three different extraction methods [9]: vacuum distillation, liquid-liquid extraction and a sorbent trapping method (Chromosorb 105). A total of 126 components were then identified by GC-MS (Table 1). The three methods were also qualitatively compared in terms of rapidity, fraction recovery and reproducibility [20]. Vacuum distillation allows a more efficient, preferential extraction of alcohols, including terpene alcohols. Liquid-liquid extraction is less reproducible but allows isolation of compounds of different classes and gives a better recovery of ionones. The sorbent trapping method uses a stream of $\mathrm{N}_{2}$ to strip the volatile compounds, which are then trapped on Chromosorb 105: this method is rapid and reproducible with a preferential recovery of monoterpenes [20]. In a later work, Guichard compared this trapping method [21] with the method used by Rapp and Knipser, originally optimized for wine aroma extraction [39], which also uses a stream of $\mathrm{N}_{2}$ but volatile components are trapped in a solvent (trichlorofluoromethane) [39]. Reproducibility was worse with Rapp and Knipser's method than with sorbent trapping, especially for the terpene fraction [21].

Larsen and co-workers quantified 20 compounds (Table 1) considered important for raspberry aroma/flavor in 10 varieties (Rubus idaeus cv. Camenzind, Chilcotin, Glen Prosen, Glen Moy, Glen Clova, Meeker, Rutrago, Skeena, Vaten and Zenith) [15]. Volatile components were extracted by solvent extraction of mashed fruits, and separation and identification of selected compounds was achieved by GC-MS with a combination of columns coated with polar (Carbowax 20M) and non-polar (HP1) stationary phases [15].

Robertson and co-workers trapped the volatile compounds flushed by a zero-air gas flow over flowers or intact berries of Rubus idaeus cv. Glen Prosen in Haysep Q or Tenax TA tubes [19]. The trapped volatiles were than analyzed by automated thermal desorption-gas chromatography-mass spectrometry equipped with a medium polarity column (DB 1701): 61 chemical compounds were identified [19] (Table 1) by comparing retention time and acquired mass spectra with those reported in MS-libraries or published reports.

The major compound found in ripe fruit was ethyl acetate $(12 \%-18 \%)$, followed by several terpenes (Table 1).

Malowicki and co-workers used the stir bar sorptive extraction (SBSE) to trap the volatile components from the juice of frozen raspberries (Rubus idaeus cv. Meeker, Chilliwack, Tulameen, 
Yellow Meeker, Willamette) and analyzed them by GC-MS [22,23]. Separation was carried out using a polar column (ZB-FFAP). They were able to identify 29 volatile compounds (confirmed with authentic standards) (Table 1) showing quantitative differences between cultivars and between different growing sites for the same cultivar [22].

Aprea and co-workers studied the volatile compounds released by the mashed fruits and juices of two raspberry cultivars (Rubus idaeus cv. Tulamen, Polka) by means of two rapid, solvent-free headspace methods: dynamic headspace by Proton-Transfer Reaction Mass Spectrometry (PTR-MS) and semi-static headspace solid phase micro-extraction (SPME) [24]. The GC-MS analysis of SPME trapped volatiles resulted in identification of 45 compounds ( 28 of which confirmed by authentic reference) while PTR-MS, a direct injection mass spectrometer [40], allowed the monitoring of hundreds of mass spectrometric signals, 29 of which were tentatively identified and 4 had established identities (Table 1). The same SPME-GC-MS procedure with separation carried out in a polar fused-silica capillary column (HP-Innowax) was used to compare the volatile profiling of different raspberry varieties (Rubus idaeus cv. Anne, Autumn Bliss, Caroline, Heritage, Himbo Top, Josephine, Opal, Pokusa, Polana, Polesie, 2 Polka accessions, Popiel, Tulameen) [13]: the 45 compounds identified are reported in Table 1.

Vrhovsek et al., quantified 39 volatile compounds (Table 1) in a solvent extract of 5 raspberry varieties (Rubus idaeus cv. Autumn Treasure, Glen Ample, Himbo Top, Rubyfall and Sugana) using GC-triple quadrupole MS/MS [16]. GC separation was performed on a polar (VF-WAXms) capillary column. The five varieties investigated differed in both qualitative and quantitative volatile compound composition.

A total of 276 volatile compounds are reported in Table 1 (note that three entries refer to undetermined isomers of reported compounds). Data are collected from the 20 papers dealing with raspberry fruit volatile compounds reviewed in this section. Of the 276 volatile compounds reported in raspberry, 141 have been confirmed by comparison with authentic standards (references in bold in Table 1). Figure 1 shows distribution of the 276 volatile compounds according to chemical class.

The largest class of compounds is constituted by the 56 monoterpenes reported (we use the term terpene to indicate both terpenes and terpenoids). Of these, terpinen-4-ol, geraniol, linalool, limonene, nerol, $p$-cymene, terpinolene, $\alpha$ - and $\beta$-phellandrene, $\gamma$-terpinene and $\alpha$ - and $\beta$-pinene are the most frequently reported. Terpenes derive from the common building unit isopentenyl diphosphate (IDP) and its isomer dimethylallyl diphosphate (DMADP) [41]. In plants, two parallel pathways lead to the formation of both IDP and DMADP: the mevalonate (MVA) pathway, which is active in the cytosol, and the methylerythritol 4-phosphate (MEP) pathway, which is active in the plastid. It is generally acknowledged that monoterpenes are synthesized in the plastids whereas sesquiterpenes are produced in the cytosol [42], with some exceptions [43].

A total of 38 volatile acids are reported in Table 1. A characteristic of raspberry volatile composition is the relatively high amounts of some of these volatile acids. Acetic acid is reported to be between $20 \mathrm{ppb}$ and $135 \mathrm{ppm}$, the wide variability mainly attributed to variety differences [15]. Hexanoic and octanoic acids are reported at concentrations up to $19.3 \mathrm{ppm}$ and $600 \mathrm{ppb}$, respectively.

Only three of the 11 sesquiterpenes found in raspberry fruits were quantified: $(E)$ - $\beta$-caryophyllene, $\alpha$-elemene and caryophyllene oxide.

Ten C13-norisoprenoids have been reported in raspberry up to now. These compounds are generated by oxidative cleavage of the carotenoids [44] and most of them are known to be important contributors to raspberry fruit aroma (see also paragraph 4.1). 


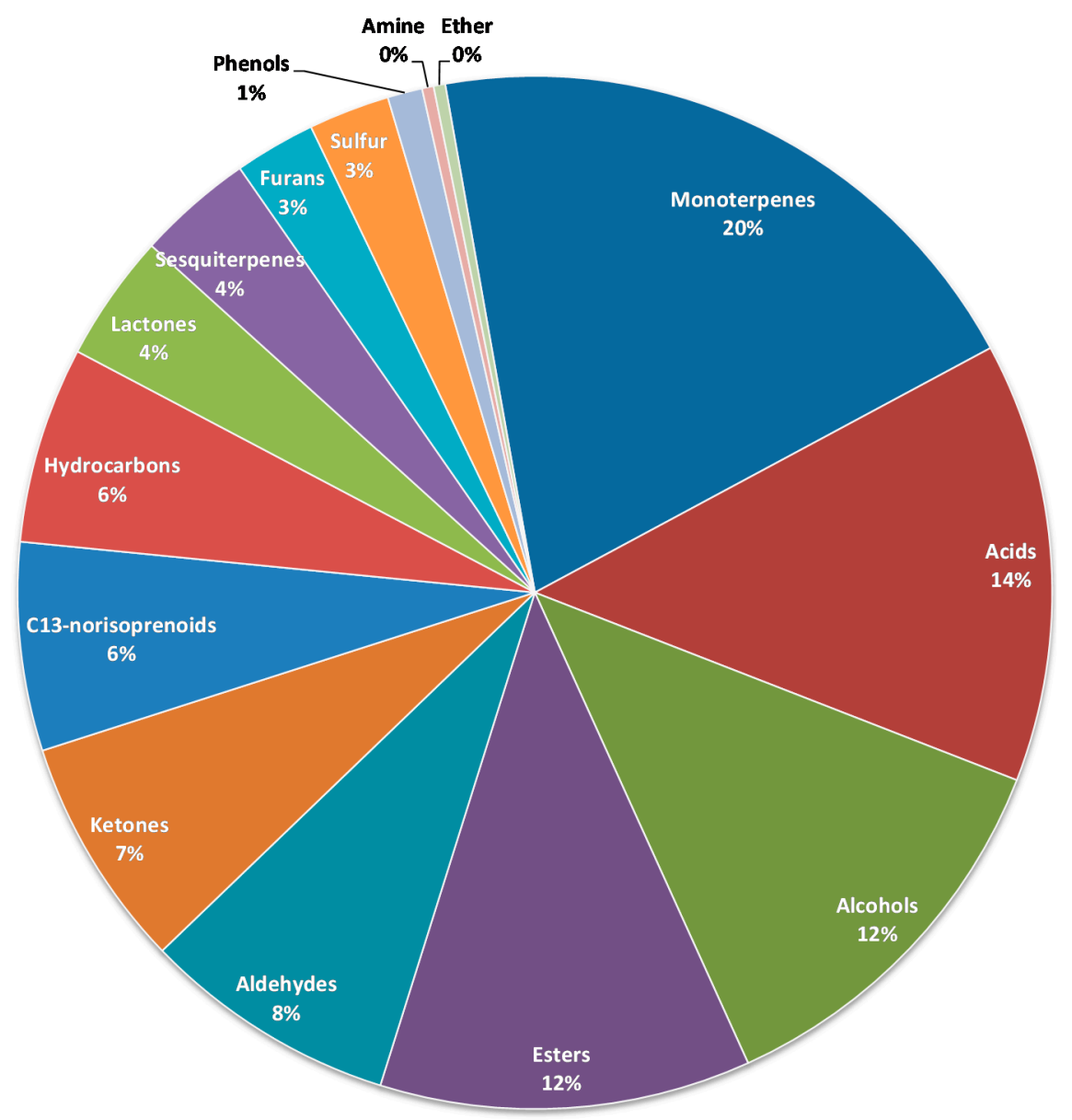

Figure 1. Volatile compounds reported in raspberry fruit (Rubus idaeus L.) according to chemical class.

Some compounds were reported by only one or two authors, others more frequently. Nine compounds were reported in at least half the cited works: (Z)-3-hexen-1-ol; 1-hexanol; hexanal; (Z)-3-hexenyl acetate; terpinen-4-ol; geraniol; linalool; $\alpha$-ionone; $\beta$-ionone. The reported concentrations of these compounds are generally all above $100 \mathrm{ppb}$, except for (Z)-3-hexenyl acetate (between 3 and $11 \mathrm{ppb}$ ). The first four molecules, (Z)-3-hexen-1-ol, 1-hexanol, hexanal, $(Z)$-3-hexenyl acetate, are commonly produced by plants and are generally indicated as leaf compounds; all are characterized by green odors which have a higher intensity in (Z)-3-hexen-1-ol. Terpinen-4-ol, geraniol, linalool are among the major terpineols contributing to the floral scent found in fruits [45]. Other nine monoterpenes and terpenoids are reported at concentrations above $100 \mathrm{ppb}$ (Table 1). $\alpha$-Ionone and $\beta$-ionone are two important carotenoid-derived aroma volatile compounds [46] responsible for floral notes; indeed the odor of $\beta$-ionone is described as raspberry-violet [47].

Concentrations of volatile compounds observed by various authors in raspberry fruits can vary several-fold (Table 1). These differences are generally attributed to particular characteristics of raspberry cultivars or non-homogeneity of the fruit ripening stage. In one of the most recent works [16], the concentrations of the different volatile compounds were, in most cases, reported to be two orders of magnitude lower than previous findings. Direct comparison of the quantities reported by different authors is not feasible because of the different extraction methods and quantification procedures used. 
Most papers do not report recoveries of the extraction method used, and when carrying out quantitative procedures the matrix effect is most of the time not taken into account when calibration curves are built.

\subsection{Glycosidically-Bound Compounds}

A large number of volatile compounds, several of them with odor activity, are glycosylated and accumulate as non-volatile and flavorless glyco-conjugates in plant tissues [48]. These glycosidically-bound compounds are present in several fruits [48] and their occurrence is typically two to eight times greater than that of their free forms $[49,50]$.

Pabst and collaborators studied glycosidically-bound volatiles in raspberry fruit (Rubus idaeus cv. Heritage) after enzymatic hydrolysis [51]. In total, 57 bound aglycons originating from fatty acid, phenylpropanoid, and terpene metabolisms were separated by GC on a Chrompack fused silica CP-Wax-58-CB WCOT capillary column and identified by MS using reference standards. Terpenes and C13-norisoprenoids were the largest classes with 14 and 12 compounds each respectively, followed by alcohols with 11 compounds, and acids with nine compounds. The other 11 compounds were seven phenols, one furane, one ketone and three lactones (Table 2).

More recently, Vrhovsek et al. quantified the amounts of 24 glycosidically-bound compounds in five raspberry varieties (Rubus idaeus cv. Autumn Treasure, Glen Ample, Himbo Top, Rubyfall and Sugana) [16]. This group developed a selective GC/MS/MS method for quantitative metabolite profiling of volatile compounds in apple, grapes and raspberries [16]. The volatile compounds were extracted from frozen powder of the fruits according to the solid phase extraction method reported in previous works $[49,52]$. Compound separation was carried out on a polar (VF-WAXms) capillary column. The compounds belonging to several classes, alcohols (4), aldehydes (4), terpenes (4), C13-norisoprenoids (7), one sesquiterpene, one acid, one ester, one lactone and one ketone, are reported in Table 2 with quantitative information. Several of the compounds identified are present in bound form with concentrations 2 to 40 times higher than their free forms (Table 2). In the cultivar Autumn Treasure the bound form of benzyl alcohol is 44.7 times that of the free form. The amount of $\alpha$-ionol present as glycol-conjugate is 40.7 and 27.5 times that of the free form in Himbo Top and Rubyfall varieties, respectively. $\beta$-damascenone was found only in bound form in the varieties investigated.

Table 2. Glycosidically-bound volatiles reported in raspberry fruit (Rubus idaeus L.).

\begin{tabular}{lcc}
\hline \multirow{2}{*}{ Compounds ${ }^{a}$} & \multicolumn{2}{c}{ Literature } \\
\cline { 2 - 3 } \multicolumn{1}{c}{ Acids } & from [51] & from [16] (mg/Kg) ${ }^{b}$ \\
\hline (E)-Cinnamic acid & $\mathrm{X}$ & \\
$(Z)$-Cinnamic acid & $\mathrm{X}$ & \\
3-Methylbutanoic acid & $\mathrm{X}$ & \\
Acetic acid & $\mathrm{X}$ & \\
Benzoic acid & $\mathrm{X}$ & \\
Butanoic acid & $\mathrm{X}$ & \\
Hexadecanoic acid & $\mathrm{X}$ & \\
Hexanoic acid & $\mathrm{X}$ & $0.01775-0.42944$ \\
Octanoic acid & $\mathrm{X}$ & \\
\hline
\end{tabular}


Table 2. Cont.

\begin{tabular}{|c|c|c|}
\hline \multirow{2}{*}{ Compounds ${ }^{a}$} & \multicolumn{2}{|r|}{ Literature } \\
\hline & from [51] & from $[16](\mathrm{mg} / \mathrm{Kg})^{b}$ \\
\hline \multicolumn{3}{|l|}{ Terpenes and Sesquiterpenes } \\
\hline (6E)-8- Hydroxylinalool & $\mathrm{X}$ & \\
\hline Homovanillyl alcohol & $\mathrm{X}$ & \\
\hline 4-Terpineol & $X$ & \\
\hline Eugenol & $X$ & \\
\hline Geraniol & $X$ & $0.01254-0.03740$ \\
\hline Isoeugenol & $\mathrm{X}$ & \\
\hline Linalool & $X$ & $0.00189-0.02361$ \\
\hline Myrtenol & $\mathrm{X}$ & $0.00021-0.00225$ \\
\hline Nerol & $\mathrm{X}$ & \\
\hline Propiovanillone & $X$ & \\
\hline Raspberry ketone & $X$ & \\
\hline Vanillin & $\mathrm{X}$ & \\
\hline Zingerone & $X$ & \\
\hline$\alpha$-Terpineol & $\mathrm{X}$ & \\
\hline$p$-Cymene & & $0-0.00003$ \\
\hline Caryophyllene oxide & & $0.00103-0.02543$ \\
\hline \multicolumn{3}{|l|}{ Alcohols } \\
\hline (E)-2-Hexen-1-ol & $\mathrm{X}$ & \\
\hline (E)-Cinnamyl alcohol & $X$ & \\
\hline (Z)-3-Hexen-1-ol & $\mathrm{X}$ & $0.00197-0.00692$ \\
\hline 1-Hexanol & $X$ & $0.00291-0.01024$ \\
\hline 1-Octanol & $X$ & \\
\hline 1-Phenylprop-2-en-1-ol & $\mathrm{X}$ & \\
\hline 2-Heptanol & $\mathrm{X}$ & $0.00144-0.00561$ \\
\hline 2-Phenylethanol & $\mathrm{X}$ & \\
\hline 3-Phenyl-1-propanol & $\mathrm{X}$ & \\
\hline 6-Methyl-5-hepten-2-ol & $X$ & \\
\hline Benzyl alcohol & $X$ & $0.09488-0.36197$ \\
\hline \multicolumn{3}{|l|}{ Phenols } \\
\hline Phenol & $X$ & \\
\hline 2-Methoxy-4-vinylphenol & $\mathrm{X}$ & \\
\hline Dihydroconiferyl alcohol & $X$ & \\
\hline 4-Methylphenol & $\mathrm{X}$ & \\
\hline 4-Vinyl-2,6-dimethoxyphenol & $\mathrm{X}$ & \\
\hline 4-Vinylsyringol & $\mathrm{X}$ & \\
\hline Tyrosol & $X$ & \\
\hline \multicolumn{3}{|l|}{ Aldehydes } \\
\hline Benzaldehyde & & $0.00195-0.01468$ \\
\hline Decanal & & $0.00072-0.00173$ \\
\hline Hexanal & & $0.00169-0.00557$ \\
\hline 5-(Hydroxymethyl)furfural & & $0-0.00110$ \\
\hline
\end{tabular}


Table 2. Cont.

\begin{tabular}{|c|c|c|}
\hline \multirow{2}{*}{ Compounds ${ }^{a}$} & \multicolumn{2}{|r|}{ Literature } \\
\hline & from [51] & from $[16](\mathrm{mg} / \mathrm{Kg})^{b}$ \\
\hline \multicolumn{3}{|l|}{ C13-norisoprenoids } \\
\hline 3,4-Didehydro- $\beta$-ionone & $\mathbf{X}$ & \\
\hline 3-Hydroxy-5,6-epoxy- $\beta$-ionone & $\mathrm{X}$ & \\
\hline 3 -Hydroxy- $\alpha$-ionone & $\mathbf{X}$ & \\
\hline 3 -Hydroxy- $\beta$-damascone & $\mathbf{X}$ & \\
\hline 3-Hydroxy- $\beta$-ionone & $\mathbf{X}$ & \\
\hline 3-Oxo-7,8-dihydro- $\alpha$-ionol & $\mathbf{X}$ & \\
\hline 3-Oxo- $\alpha$-ionol & $\mathbf{X}$ & \\
\hline 4-Hydroxy- $\beta$-ionone & $\mathbf{X}$ & \\
\hline 4-Oxo- $\beta$-ionol & $\mathbf{X}$ & \\
\hline Theaspirane A & $\mathbf{X}$ & $0.00024-0.00188$ \\
\hline Theaspirane B & $\mathbf{X}$ & $0.00024-0.00185$ \\
\hline$\alpha$-Ionol & $\mathbf{X}$ & $0.00506-0.19229$ \\
\hline$\beta$-Damascenone & & $0-0.00062$ \\
\hline$\beta$-Ionol & & $0.00013-0.00667$ \\
\hline$\beta$-Ionone & & $0.00037-0.00187$ \\
\hline$\alpha$-Ionone & & $0.00018-0.00063$ \\
\hline furane, ketone, esters and lactones & & \\
\hline $\begin{array}{l}\text { 2,5-Dimethyl-4-hydroxy-3 }(2 H) \\
\text { furanone }\end{array}$ & $\mathbf{X}$ & \\
\hline 4-Hydroxyacetophenone & $\mathbf{X}$ & \\
\hline$\delta$-Decalactone & $\mathbf{X}$ & $0.00554-0.02189$ \\
\hline$\delta$-Octalactone & $\mathbf{X}$ & \\
\hline (Z)-Jasmone & & $0.00025-0.00127$ \\
\hline Methyl 2-hydroxybenzoate & & $0.00007-0.00023$ \\
\hline
\end{tabular}

a The identity of compounds has been confirmed by comparison with authentic standards but for 3-hydroxy-5,6-epoxi- $\beta$-ionone. ${ }^{b}$ Quantitative data obtained after solvent extraction of mashed fruit by GC-triple quadrupole methods using authentic standards. "X" refers to identified but not quantified compounds.

\subsection{Enantiomeric Distribution}

Natural volatile molecules are generally found with one enantiomer predominating, attributable to stereoselectively controlled biogenetic formation mechanisms [53]. It is also known that certain enantiomeric chemicals have different sensory properties in terms of both odor quality and intensity [54]. Therefore, knowing the enantiomeric distribution of chiral compounds may help in understanding aroma perception. Furthermore, enantioselectivity and isotope discrimination during biosynthesis have been recognized as important indicators of authenticity of the natural product [55] and as such represent a useful method for differentiating natural raspberry products from those adulterated with synthetic aromas [56].

Nitz and co-workers determined the enantiomeric distribution of seven $\gamma$-lactones in deep-frozen raspberry (unknown variety) by multi-dimensional GC with achiral-chiral column combinations [57]. They found $\gamma$-octalactone and $\gamma$-hexalactone predominating with 65 and $30 \mathrm{ppb}$, respectively, and a 
prevalence of $(S)$ enantiomers. The other $\gamma$-lactones had concentrations of $5 \mathrm{ppb}$ or less with a prevalence of $(S)$ enantiomers for hepta-, nona- and undeca- lactones, while a racemic distribution was observed for the deca-, and dodeca- lactones.

Werkhoff and co-workers found that $99.9 \%$ of $\alpha$-ionone is present in raspberry as $(R)$ enantiomer [58]. The same result was obtained by Casabianca and Graff, who studied the enantiomeric distribution of $\alpha$-ionone and $\delta$-decalactone in three raspberry cultivars (Rubus idaeus cv. Mecker, Heritage and Williamette) and commercial raspberry products (tea, syrup and juice) [56]. One enantiomer was predominant in raspberry fruit while commercial product prepared with synthetic flavors displayed a racemic distribution of the two enantiomers. The $(R)$ enantiomer of $\alpha$-ionone was found to be more than $98 \%$. In contrast, the $(S)$ form was more than $98 \%$ in $\delta$-decalactone. The results for $\alpha$-ionone were corroborated by Sewenig et al. [59] in different raspberry varieties (Rubus idaeus cv. Rucami, Schönemann-Meyer, Meeker, Rumiloba, Glen Ample and Tulameen).

Malowicki and co-workers reported the isomeric ratios of $\alpha$-ionone, $\alpha$-pinene, linalool, terpinen-4-ol, $\delta$-octalactone, $\delta$-decalactone and 6-methyl-5-hepten-2-ol in several raspberry varieties (Rubus idaeus cv. Meeker, Chilliwack, Tulameen, Yellow Meeker, Willamette) [22]. Isomeric ratios for lactones and $\alpha$-ionone were in agreement with previous studies. Linalool was almost a racemic mixture, with a slightly higher percentage of the $(S)$-isomer. In terpinen-4-ol the $(S)$ isomer was about $80 \%$. For 6-methyl-5-hepten-2-ol it was not possible to ascertain which enantiomers eluted first and were indicated as enantiomer 1 with abundances from $77 \%$ to $86 \%$ and enantiomer 2 . Finally, $\alpha$-pinene was found to be present only as $(R)$-isomer. Table 3 summarizes the enantiomeric distribution of the selected compounds isolated from raspberry fruits reviewed in this section.

Table 3. Enantiomeric composition of selected compounds reported in raspberries (Rubus idaeus L.).

\begin{tabular}{|c|c|c|c|}
\hline \multirow{2}{*}{ Compound } & \multicolumn{2}{|c|}{ Enantiomer } & \multirow{2}{*}{ Reference } \\
\hline & $R(\%)$ & $S(\%)$ & \\
\hline$\gamma$-Hexalactone & 34 & 66 & [53] \\
\hline$\gamma$-Heptalactone & 25 & 75 & {$[53]$} \\
\hline$\gamma$-Octalactone & 44 & 56 & {$[53]$} \\
\hline$\gamma$-Nonalactone & 28 & 72 & {$[53]$} \\
\hline$\gamma$-Decalactone & 49 & 51 & [53] \\
\hline$\gamma$-Undecalactone & 55 & 45 & [53] \\
\hline$\gamma$-Dodecalactone & 50 & 50 & {$[53]$} \\
\hline$\delta$-Octalactone & $0-6$ & $94-100$ & {$[32]$} \\
\hline \multirow[t]{2}{*}{$\delta$-Decalactone } & $0-2$ & $98-100$ & {$[52]$} \\
\hline & $0-3$ & $97-100$ & {$[32]$} \\
\hline \multirow[t]{4}{*}{$\alpha$-Ionone } & 99.9 & 0.1 & [54] \\
\hline & $98-100$ & $0-2$ & {$[52]$} \\
\hline & $>99.9$ & - & {$[55]$} \\
\hline & $97-99$ & $1-3$ & {$[32]$} \\
\hline$\alpha$-Pinene & 100 & 0 & {$[32]$} \\
\hline Linalool & $36-51$ & $49-64$ & {$[32]$} \\
\hline Terpinen-4-ol & $18-21$ & $79-82$ & [32] \\
\hline
\end{tabular}




\subsection{Formation and Development}

\subsubsection{Development during Ripening}

Fruit ripening is a highly coordinated, genetically programmed, irreversible phenomenon involving a series of physiological, biochemical, and sensory changes that lead to the development of a soft, edible ripe fruit with desirable attributes [60]. During ripening the odor and flavor of the fruits develop through the production of several volatile and non-volatile compounds (sugars, acids) and/or degradation of bitter principles (flavonoids, tannins, and related compounds) [61].

Guichard followed the evolution of different volatile compounds in two raspberry varieties (Rubus idaeus cv. Lloyd George and Rose de Côte d'Or) during ripening [62]. Four stages of ripening were identified: green-pink, pink, ripe and over-ripe. In both varieties all the terpenes and sesquiterpenes measured ( $\alpha$-pinene, $\beta$-pinene, myrcene, $\alpha$-phellandrene, $p$-cimene, $\beta$-phellandrene, $\gamma$-terpinene, caryophyllene and humulene) greatly increased during ripening. The chromatographic peak areas varied from 10 to 1000 for the different terpenes and sesquiterpenes. Esters (isopentyl-, pentenyl-, (Z)-3-hexenyl- and methyl- acetate) also increased 10-100 fold during ripening. Geraniol was at its highest at the ripening stage in the cultivar Lloyd George but continued to increase up to the over-ripe stage in the cultivar Rose de Côte d'Or. Dihydro- $\beta$-ionone was at its highest at the ripe stage then decreased. $\alpha$-Ionone increased slightly during ripening in both varieties, while $\beta$-ionone increased slightly only in Lloyd George and not at all in Rose de Côte d'Or.

Robertson and co-workers included the flowering stages in their study of the evolution of volatile compounds in raspberry [19]. They sampled volatile compounds at six sequential stages of inflorescence development in the raspberry (Rubus idaeus) cultivar Glen Prosen: green buds, flowers, old flowers/early green fruit, green fruit, pink fruit, mature red fruit. During raspberry ripening, the saturated aldehydes from six to 10 atom carbons increase steadily, as did several monoterpenes such as $\alpha$-pinene, camphene, $\alpha$-phellandrene and limonene, in agreement with previous observations [62]. However, the two terpenes $(E)$ - and $(Z)$-ocimene and the ester $(Z)$-3-hexenyl acetate greatly decreased. The terpene $\alpha$-copaene and the sesquiterpene $\beta$-caryophyllene reached a maximum at the green stage then decreased considerably during berry ripening. The two ionones $\alpha$ - and $\beta$ - only appeared during the last two stages of ripening as did the three esters methyl acetate, propyl acetate and ethyl hexanoate [19].

\subsubsection{Postharvest Development}

Boschetti et al. measured the volatile compounds in raspberry [25] by direct injection method. They used a Proton Transfer Reaction Mass Spectrometer (PTR-MS) to monitor the emission of volatile organic compounds during postharvest aging of six different kinds of berry including the raspberry cultivar Tulameen. Using PTR-MS it was possible to monitor VOC emission from individual or small quantities of intact berries in real time and at high sensitivity without the need for any treatment or accumulation method [25].

Raspberries were monitored for three consecutive days before they started to decay at the end of the third day. The highest emissions recorded on the first day were methanol, acetaldehyde (4-5 ppm) and ethanol (1 ppm). Methanol, a major volatile associated with aging, reached a concentration of $40 \mathrm{ppm}$. Masses related to esters were constant and below $10 \mathrm{ppb}$ over the three days [25]. It was suggested that 
simultaneous monitoring of the emissions of a large number of volatiles in real time and at high sensitivity can be used to describe fruit products and processing [25].

\subsubsection{Fast Processes}

Aprea et al. monitored real time release of VOCs during mashing of the fruit [24] to simulate what happens during chewing or what could be the consequence of fruit damage during handling. In general, volatile emission increases after crushing of the fruits as the physical barriers trapping these secondary plant metabolites are disrupted. As well as the preformed plant metabolites, several other compounds of neo-formation (mainly oxidation product) are released. Figure 2, taken from Aprea et al. [24], reports the development over time of selected compounds monitored during raspberry crushing. At $10 \mathrm{~min}$ from the beginning of the experiment (indicated by the arrow) a sudden increase in the volatile compounds emitted occurs. Methanol, acetate ester, and acetic acid signals increase 4- to 5-fold in less than 1 min. (Z)-3-Hexenol increases 13-fold, while the peak in the C6-VOC signal after $4 \mathrm{~min}$ represents a 150-fold increase. These latter compounds together with $\mathrm{C} 5$-VOC are typical wounding products emitted by leaves and fruits, which originate from the lipoxygenase and hydroperoxide lyase pathways and are responsible for the typical green notes of fruits and leaves when crushed [63].

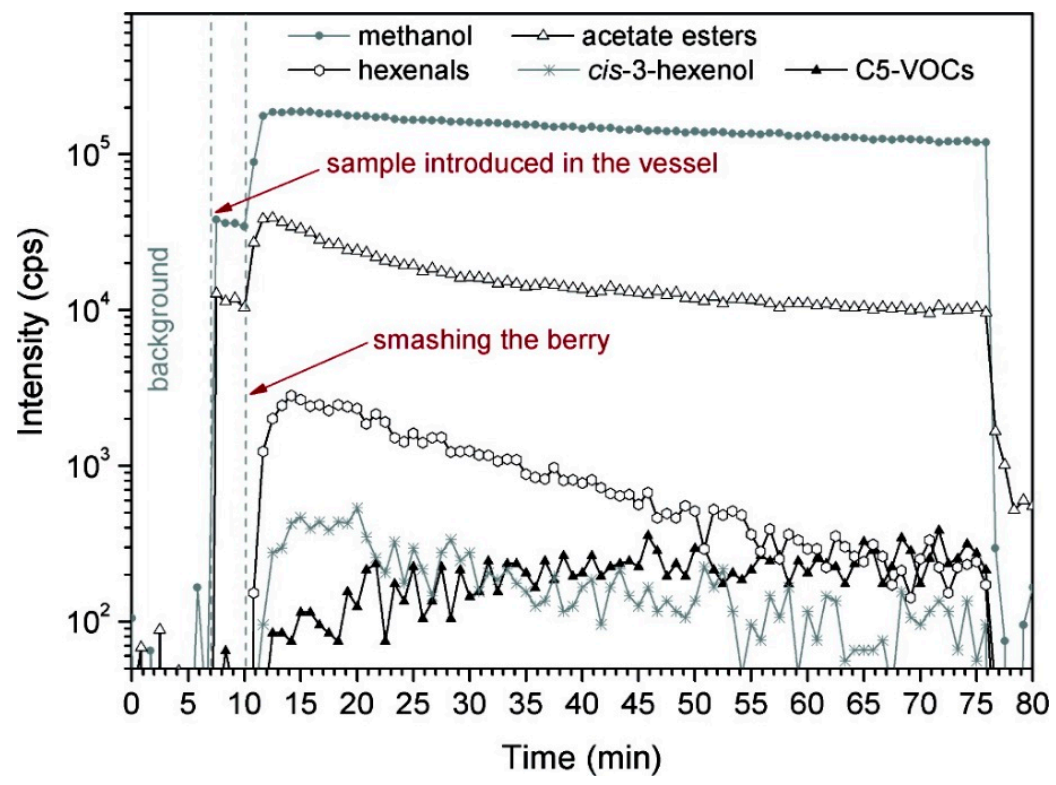

Figure 2. Real-time PTR-MS monitoring of VOCs released during crushing of raspberry fruit. Reproduced with permission from [24]. Copyright (C) 2009 American Chemical Society.

The experiment revealed that compounds produced by plant metabolism and accumulated in fruit tissue or constantly released, such as acetate esters, and compounds that are a direct consequence of tissue damage, such as C6-VOCs, have different release patterns. Since these compounds are also produced during food consumption they could affect sensory perception of the berries. The study mentioned in this section [24] was carried out using instruments coupled with a quadrupole mass analyzer which provides only the nominal mass of the observed spectrometric peaks, and therefore 
several interferences cannot be excluded (a version of the instrument coupled with time of flight mass spectrometry which improves the capacity of compounds identification is currently available [64]).

\subsection{Odor-Active Compounds}

Few of the many volatile compounds reported in raspberry (Tables 1 and 2) are recognized as important for the aroma of this fruit. One of the first compounds to be identified as having an impact on the character of raspberry is 4-(4-hydroxyphenyl)butan-2-one [38], which for this reason was named raspberry ketone. This compound is synthetized in Rubus idaeus by condensation of $p$-coumaroyl-CoA with malonyl-CoA and successive reduction [65]. Borejsza-Wysocki and co-workers measured the content of raspberry ketone in six raspberry cultivars (Rubus idaeus cv. Camby, Meeker, ORUS 576-47, ORUS 2078, Royalty and Willamette) and subjected them to organoleptic evaluation [66]. The 11 judges scored the varieties on a 0-100 scale for intensity of "raspberry" flavor and aroma. The highest flavor score (56.2) was obtained for the Willamette variety, which had the highest raspberry ketone content of the six raspberry cultivars investigated [66]. In their study, Larsen and co-workers identified raspberry ketone and $\alpha$ - and $\beta$-ionone as the most important aromas in the 10 different raspberry varieties investigated (Rubus idaeus cv. Camenzind, Chilcotin, Glen Prosen, Glen Moy, Glen Clova, Meeker, Rutrago, Skeena, Vaten and Zenith) [15]. They confirmed that pure raspberry aroma was highly dependent on raspberry ketone content, while $\alpha$ - and $\beta$-ionone were found to be important for the overall aroma. $\alpha$-Ionone in raspberry is known to be present in the $(R)$-enantiomeric form [33,34,67], which is reported to produce a violet-like, fruity, raspberry-type, floral odor [68], while $\beta$-ionone is described as "fragrant" and "floral" [69].

Klesk and co-workers investigated odor-active compounds in red raspberry cultivar Meeker by Aroma Extract Dilution Analysis (AEDA) [10]. This technique involves the flavor extract being sequentially diluted and each dilution analyzed by GC-O by a small number of judges. The flavor dilution (FD) of an odorant corresponds to the maximum dilution at which that odorant can be perceived by at least one of the judges [70]. Although FD factors do not conclusively establish that one sample contains more of a given aroma compound than another, it gives an indication of the compounds that may contribute to the overall aroma of a product. Klesk and co-workers identified 75 odor-active volatiles (see Table 1) in the Meeker raspberry cultivar from two locations in the United States (Oregon and Washington) [10]. Compound identifications were confirmed by injection of authentic standards. The most intense compounds found in both samples included strawberry furanone, hexanal, $\beta$-ionone, (E)- $\beta$-ocimene, 1-octanol, $\beta$-pinene, (FD 2048), $\beta$-damascenone (FD 512), acetic acid, (Z)-3-hexenal, methional (FD 256), (Z)-3-hexenol, and linalool (FD 128). Differences between the fruit from the two locations were found for other compounds [10]. As the authors themselves recognize, defining FD is only a first step towards measuring the true odor impact of these compounds [70], which would require chemical quantification of these potent odorants and generation of their OAVs to be carried out. 


\subsection{Genetic Diversity}

\subsubsection{Wild Raspberries}

In 1980 Honkanen et al. carried out qualitative and quantitative comparisons of the volatile compounds in Finnish wild raspberries and in two cultivated varieties (Ottawa and Preussen) using GC-MS [11]. Volatile compounds were isolated from pentane/ethyl ether in raspberry juice extract and GC separation was performed in a polar (FFAP) capillary column. A total of 75 molecules were identified (Table 1) with the aid of authentic standards. As with the cultivated varieties, volatile acids (especially acetic and hexanoic) in the wild varieties were found to be present in high concentrations (24 ppm). The authors reported the presence in wild raspberries of two acids, 3-methyl-2-butenoic and 3-methyl-3-butenoic, which have not been found in any other cultivated raspberry. A few terpenes and sesquiterpenes have been found to be specific to wild raspberries, such as $(Z)$-sabinol, menthol, and $\alpha$-elemene. The alcohol fraction in wild raspberries was reported to be about twice that of the cultivated varieties (24 and 10\%-15\%, respectively). The two trans enantiomers, 2-hexen-1-ol and 3-hexen-1-ol, not found until now in cultivated berries, were also reported to be present in wild berries. Several volatile phenolic compounds were identified in the wild berries, such as 2-methoxy-4-vinylphenol, 2-methoxy-5-vinylphenol, 3,4-dimethoxybenzaldehyde, and 4-vinylsyringol, none of which has been reported in any cultivated variety. The amount of raspberry ketone (4-(4-hydroxyphenyl)butan-2-one), one of the most important compounds impacting on raspberry flavor [38], was found to be 3 times higher in wild berries than in cultivated varieties, although the amount of $\alpha$ - and $\beta$-ionone was $1.5-2$ times lower. With the exception of ionones, the amounts of individual volatile compounds were generally 3-4 times higher in wild raspberries than in the cultivated varieties. The higher amounts of volatile compounds and the presence of several compounds only in wild raspberry species may contribute to their distinctive aroma. The authors also suggest that increased berry size as a result of breeding programs, hybridization and/or fertilization leads to a deterioration in the aroma of the berries [11].

\subsubsection{Differences among Cultivars}

Terpenes, terpenoids and nor-isoprenoid volatile compounds are the major compounds that have been examined for the differentiation of raspberry cultivars [15,22] as they are highly related to raspberry odor and flavor [15].

Larsen and co-workers reported relatively small variations in raspberry ketone and ionones in the 10 cultivars they compared (Rubus idaeus cv. Camenzind, Chilcotin, Glen Prosen, Glen Moy, Glen Clova, Meeker, Rutrago, Skeena, Vaten and Zenith) [15]. Greater differences between the varieties were observed in the concentrations of linalool, geraniol, benzyl alcohol, acetoin, acetic acid, and hexanoic acid. The high variations in the three latter compounds were ascribed to differing enzymatic activity influenced by both variety and different degrees of ripeness [15].

Malowicki et al. reported large variations in $\alpha$-ionone, $\beta$-ionone, geraniol, linalool, and $(Z)$-3-hexenol in different raspberry cultivars (Rubus idaeus cv. Meeker, Chilliwack, Tulameen, Yellow Meeker, Willamette) [22].

In a more recent work, Aprea et al. compared the head space SPME GC-MS profile of 14 different raspberry cultivars (Rubus idaeus cv. Anne, Autumn Bliss, Caroline, Heritage, Himbo Top, Josephine, 
Opal, Pokusa, Polana, Polesie, two Polka accessions, Popiel, Tulameen) over two consecutive production seasons (2006 and 2007) [13]. Volatile compounds were separated in a polar fused-silica capillary column (HP-Innowax). All fruits were harvested in the same experimental field using the same agronomic practices. Crop season strongly influenced the total volatile emissions. In 2007 the raspberries had higher amounts of volatile compounds (two fold for many varieties), which was attributed to the colder temperatures (and higher thermic excursions) recorded over the 2007 season in the experimental fields, located in Vigolo Vattaro (Trento, Italy) [13]. Similar effects due to temperature excursions were reported in previous works $[30,71]$. Nonetheless, the assembled data set allowed raspberry varieties to be clustered in groups of similar volatile patterns. In general, Polka and Popiel were characterized by low amounts of volatile compounds, while Caroline, Heritage, Himbo-top, and Josephine were much richer. Levels of terpene alcohols and C13-norisoprenoid compounds were found to be higher in Anne, Polana, Polesie, Polka-I, Polka-P, and Popiel, while monoterpenes and sesquiterpenes were higher in Autumn Bliss, Caroline, Heritage, Himbo Top, Josephine, Opal, Pokusa, and Tulameen. Tulameen was further differentiated for the amounts of C6 compounds (aldehydes and alcohols) and their esters [13]. In a subsequent study, advanced chemometric methods were used to classify the same 14 cultivars using both GC data and PTR-MS measurements [72]. Specifically, random forest (RF), penalized discriminant analysis (PDA), discriminant partial least Squares (dPLS) and support vector machine (SVM) were used for cultivar classification, and random forest-recursive feature elimination (RF-RFE) was used for feature selection [72]. These analyses revealed 2-heptanone, 2-heptanol, $(E)$-caryophyllene, and dehydro- $\beta$-ionone to be the most useful compounds for raspberry cultivar classification. Thus, not only terpenes and derivative compounds, as suggested in previous works [15,22], but also other classes of compounds may contribute to the characterization of raspberry cultivars. These cultivar differences are then reflected in the diverse aroma and possible defense mechanisms (see Section 2.8) of the selected raspberry varieties.

\subsection{Environmental and Seasonal Effects}

The raspberry fruit produces an array of volatile compounds with significant variations in their contents influenced by numerous factors including genotype, climate, soil, ripeness, and many other variables $[2,10,11,13,19,22,30]$ that impact on odor and flavor.

Paterson and co-workers studied environmental and seasonal impacts over two seasons on the contents of twelve raspberry character volatiles ( $\alpha$-ionone, $\alpha$-ionol, $\beta$-ionone, $\beta$-damascenone, linalool, geraniol, benzyl alcohol, (Z)-3-hexenol, acetoin, acetic, hexanoic acids and raspberry ketone) obtained from plants from the Glen Moy x Latham mapping population growing in open field or under cover (polytunnels) [14]. As reported in a previous work [13], significant seasonal variation $(p<0.001)$ was observed between field fruit for all volatiles except $\beta$-damascenone and acetoin. Seven volatiles were more abundant in polytunnel berries but $\beta$-damascenone and $\beta$-ionone were less abundant. Thus both season (2006/2007) and environment (field/polytunnel) significantly influenced the content of the monitored volatiles in raspberry fruit [14]. 


\subsection{Mold Resistance}

Raspberries are delicate fruits that soften and deteriorate rapidly after harvest. They are also highly susceptible to fungal diseases, particularly gray mold caused by Botrytis cinerea especially during postharvest storage [73]. Plants possess a range of preformed or inducible defense mechanisms, many of them involving secondary metabolites [74]. In fact, several volatile compounds are recognized for their inhibitory activity against pathogens, in particular $B$. cinerea in the case of raspberry $[75,76]$. Other studies have demonstrated that the same volatile compounds can have an opposite effect on pathogen development. For example, $(E)$-2-hexenal stimulates both $B$. cinerea spore germination and mycelial growth when present at low concentrations [77]. It was recently demonstrated that key strawberry aroma compounds stimulate $B$. cinerea conidial germination and some typical wound volatiles stimulate pathogen conidial germination or mycelial growth [78]. Thus, along with other resistance factors and defense mechanisms [79,80], volatile compounds seem to play a central role in mediating plant/pathogen interactions. Aprea et al. compared susceptibility to $B$. cinerea and volatile profiles in 14 raspberry cultivars [13] and found nine compounds to be negatively correlated with raspberry $B$. cinerea susceptibility: $\alpha$-pinene, $\beta$-phellandrene, p-cymene, 2-heptanol, 4-terpineol, (E)- $\beta$-caryophyllene, $\beta$-damascenone, dehydro- $\beta$-ionone, and caryophyllene oxide. The authors suggested that quantification of these compounds in raspberry could be used as an indicator of fruit resistance to $B$. cinerea [13]. A subsequent study confirmed the importance of dehydro- $\beta$-ionone, 4-terpineol, $p$-cymene, $(E)$ - $\beta$-caryophyllene for predicting raspberry susceptibility to $B$. cinerea [72].

\section{Conclusions and Perspectives}

Little literature on raspberry volatile compounds has appeared in the last 10 years and most of what there is concerning isolation and identification was concentrated during the period of Firmenich's pioneering work. Later, the availability of more powerful analytical techniques allowed raspberry volatile composition to be studied in greater detail but only a few investigations looked at their roles in sensory perception and the ecological and physiological implications.

Aside from their nutraceutical properties, one of most important traits of raspberries in terms of human consumption is their pleasant aroma. Only a small fraction of the volatile compounds identified in raspberry fruits contribute to the aroma, so that distinguishing odor-active compounds from other volatile compounds is an important step in aroma research. The association between volatile compounds and aroma/flavor perception in a complex matrix, such as fruit, is not straightforward. For example, multiple volatiles are responsible for aroma/flavor sensations, combinations of volatiles yield flavors differing from those expected of individual compounds, and perception of volatiles differs in different matrices [81]. Moreover, the final sensory evaluation can even be influenced by psychological and multisensory factors. The only "instrument" which can discriminate between odor active compounds and other volatile compounds is the human nose. Therefore, the primary measure of the sensory attributes of flavor and aroma is descriptive sensory analysis, typically with trained sensory panels [81]. For all the above-mentioned reasons we think that the relationship between volatile compounds and odor and flavor in raspberry is worth further investigation using appropriate methodologies. Furthermore, there is little literature on raspberry characterization by sensory 
descriptive methods. In our opinion this issue should be better addressed in future research and breeding programs. For example, it would be desirable to include sensory traits and volatile compounds in research on quantitative trait loci, as has been done for apple [82-84].

Other aspects of raspberry research, only partially addressed in the literature and deserving more attention, relate to plant communication and plant-pathogen interaction mechanisms mediated by endogenous volatile compounds, as studied in other fruit (e.g., strawberry [78]). These studies will contribute to a better understanding of some of the natural defense mechanisms activated by plants with the aim of helping agronomists to manipulate and manage them in order to reduce the use of pesticides.

The identity, biochemical pathways and release of volatile compounds in raspberry has been widely investigated, but more studies are needed to better understand the various biological roles played by the different volatile compounds in raspberry.

\section{Acknowledgments}

Authors acknowledge the financial support of the Autonomous Province of Trento "Accordo di Programma 2012/2013".

\section{Author Contributions}

E.A., F.B. and F.G. wrote the paper.

\section{Conflicts of Interest}

The authors declare no conflict of interest.

\section{References}

1. Jennings, D.L.; Carmichael, E. Anthocyanin Variation in the Genus Rubus. New Phytol. 1980, 84, 505-513.

2. Kempler, C.; Hall, H.; Finn, C.E. Raspberry. In Fruit Breeding; Badenes, M.L.; Byrne, D.H., Eds.; Handbook of Plant Breeding; Springer: New York, NY, USA, 2012; pp. 263-304.

3. Ward, J.A.; Calvin P.J.; Clement, M.; Schatz, M.; Weber, C.A.; Swanson, J.D.; Bodily, P.; Lewers, K.S.; Fernandez-Fernandez, F.; Burns, P.; et al. A draft assembly and analysis of the highly heterozygous diploid red raspberry genome (Rubus idaeus cv. Heritage). In Proceedings of Plant and Animal Genome XX Conference, San Diego, CA, USA, 4-18 January 2012; Sherago International: Jersey City, NJ, USA, 2012; p. 315.

4. Kähkönen, M.P.; Hopia, A.I.; Heinonen, M. Berry Phenolics and Their Antioxidant Activity. J. Agric. Food Chem. 2001, 49, 4076-4082.

5. Rao, A.V.; Snyder, D.M. Raspberries and Human Health: A Review. J. Agric. Food Chem. 2010, 58, 3871-3883.

6. $\quad$ Dunkel, M.; Schmidt, U.; Struck, S.; Berger, L.; Gruening, B.; Hossbach, J.; Jaeger, I.S.; Effmert, U.; Piechulla, B.; Eriksson, R.; et al. SuperScent-A database of flavors and scents. Nucl. Acids Res. 2009, 37, D291-D294.

7. Rowan, D.D. Volatile Metabolites. Metabolites 2011, 1, 41-63. 
8. Palluy, E.; Sundt, E.; Winter, M. Recherches sur les arômes. 7e communication. Analyse de l'arôme des framboises III. Les acides et esters inférieurs. HCA 1963, 46, 2297-2299.

9. Guichard, G. Identification des constituants volatils aromatiques de la variete de framboises Lloyd George [fruits congeles]. Sci. Aliment. 1982, 173-185.

10. Klesk, K.; Qian, M.; Martin, R.R. Aroma Extract Dilution Analysis of cv. Meeker (Rubus idaeus L.) Red Raspberries from Oregon and Washington. J. Agric. Food Chem. 2004, 52, 5155-5161.

11. Honkanen, E.; Pyysalo, T.; Hirvi, T. The aroma of Finnish wild raspberries, Rubus idaeus, L. Z. Lebensm.-Unters. Forch. 1980, 171, 180-182.

12. Pyysalo, T. Identification of volatile compounds in hybrids between raspberry (Rubus idaeus, L.) and arctic bramble (Rubus arciticus, L.). Z. Lebensm.-Unters. Forsch. 1976, 162, 263-272.

13. Aprea, E.; Carlin, S.; Giongo, L.; Grisenti, M.; Gasperi, F. Characterization of 14 Raspberry Cultivars by Solid-Phase Microextraction and Relationship with Gray Mold Susceptibility. J. Agric. Food Chem. 2010, 58, 1100-1105.

14. Paterson, A.; Kassim, A.; McCallum, S.; Woodhead, M.; Smith, K.; Zait, D.; Graham, J. Environmental and seasonal influences on red raspberry flavour volatiles and identification of quantitative trait loci (QTL) and candidate genes. Theor. Appl. Genet. 2013, 126, 33-48.

15. Larsen, M.; Poll, L.; Callesen, O.; Lewis, M. Relations between the Content of Aroma Compounds and the Sensory Evaluation of 10 Raspberry Varieties (Rubus idaeus L). Acta Agric. Scand. 1991, $41,447-454$.

16. Vrhovsek, U.; Lotti, C.; Masuero, D.; Carlin, S.; Weingart, G.; Mattivi, F. Quantitative metabolic profiling of grape, apple and raspberry volatile compounds (VOCs) using a GC/MS/MS method. J. Chromatogr. B 2014, 966, 132-139.

17. Sundt, E.; Winter, M. Recherches sur les arǒmes. 6e communication. Analyse de l'arǒme volatils des framboises II. Les alcools. HCA 1962, 45, 2212-2218.

18. Winter, M.; Enggist, P. Recherches sur les arǒmes. 17e communication. Sur l'arǒme de framboise, IV. HCA 1971, 54, 1891-1898.

19. Robertson, G.W.; Griffiths, D.W.; Woodford, J.A.T.; Birch, A.N.E. Changes in the chemical composition of volatiles released by the flowers and fruits of the red raspberry (Rubus idaeus) cultivar glen prosen. Phytochemistry 1995, 38, 1175-1179.

20. Guichard, E.; Issanchou, S. Extraction of Volatile Compounds from Raspberry by Different Methods-Application of Principal Component Analysis to Gas-Chromatographic Data. Sci. Aliments 1983, 3, 427-438.

21. Guichard, E. Comparison of 2 N-2 Entrainment Methods for the Extraction of Volatile Compounds from Raspberry. Sci. Aliments 1984, 4, 317-324.

22. Malowicki, S.M.M.; Martin, R.; Qian, M.C. Volatile Composition in Raspberry Cultivars Grown in the Pacific Northwest Determined by Stir Bar Sorptive Extraction-Gas Chromatography-Mass Spectrometry. J. Agric. Food Chem. 2008, 56, 4128-4133.

23. Malowicki, S.M.M.; Martin, R.; Qian, M.C. Comparison of Sugar, Acids, and Volatile Composition in Raspberry Bushy Dwarf Virus-Resistant Transgenic Raspberries and the Wild Type "Meeker" (Rubus Idaeus L.). J. Agric. Food Chem. 2008, 56, 6648-6655. 
24. Aprea, E.; Biasioli, F.; Carlin, S.; Endrizzi, I.; Gasperi, F. Investigation of Volatile Compounds in Two Raspberry Cultivars by Two Headspace Techniques: Solid-Phase Microextraction/Gas Chromatography-Mass Spectrometry (SPME/GC-MS) and Proton-Transfer Reaction-Mass Spectrometry (PTR-MS). J. Agric. Food Chem. 2009, 57, 4011-4018.

25. Boschetti, A.; Biasioli, F.; van Opbergen, M.; Warneke, C.; Jordan, A.; Holzinger, R.; Prazeller, P.; Karl, T.; Hansel, A.; Lindinger, W.; et al. PTR-MS real time monitoring of the emission of volatile organic compounds during postharvest aging of berryfruit. Postharvest Biol. Technol. 1999, 17, 143-151.

26. Winter, M.; Sundt, E. Recherches sur les arǒmes. 5e communication. Analyse de l'arǒme des framboises. I. Les constituants carbonylés volatils. HCA 1962, 45, 2195-2211.

27. Pearson, T.W.; Dawson, H.J.; Lackey, H.B. Naturally occurring levels of dimethyl sulfoxide in selected fruits, vegetables, grains, and beverages. J. Agric. Food Chem. 1981, 29, 1089-1091.

28. Wang, L.; Meng, X.; Zhang, F. Raspberry Ketone Protects Rats Fed High-Fat Diets against Nonalcoholic Steatohepatitis. J. Med. Food 2012, 15, 495-503.

29. Takata, T.; Morimoto, C. Raspberry Ketone Promotes the Differentiation of C3H10T1/2 Stem Cells into Osteoblasts. J. Med. Food 2014, 17, 332-338.

30. Jennings, D.L. Raspberries and Blackberries: Their Breeding, Diseases and Growth; Academic Press: London, UK; San Diego, CA, USA, 1988.

31. ISO: Standard 5492 Terms Relating to Sensory Analysis; International Organization for Standardization: Geneva, Switzerland, 2008.

32. E18 Committee. Terminology Relating to Sensory Evaluation of Materials and Products; ASTM International: West Conshohocken, PA, USA, 2013.

33. Kilic, A.; Kollmannsberger, H.; Nitz, S. Glycosidically Bound Volatiles and Flavor Precursors in Laurus nobilis L. J. Agric. Food Chem. 2005, 53, 2231-2235.

34. Ikan, R. Naturally Occurring Glycosides; John Wiley: Chichester, UK; New York, NY, USA, 1999.

35. Winter, M.; Palluy, E.; Hinder, M.; Willhalm, B. Recherches sur les arǒmes. 4e communication. Procédé d'isolement des constituants volatils de la fraise et de la framboise. HCA 1962, 45, 2186-2195.

36. Schinz, H.; Seidel, C.F. Untersuchungen über Aromastoffe. 1. Mitteilung. Über das Himbeeraroma. HCA 1957, 40, 1839-1859.

37. Sundt, E.; Winter, M. Untersuchungen über Aromastoffe. 3. Mitteilung. Die Isolierung von Geraniol aus Himbeeren. HCA 1960, 43, 1120-1121.

38. Winter, M. Odeur et constitution XIX. Sur des homologues et analogues de la p-hydroxyphényl-1butanone-3 («cétone de framboise»). HCA 1961, 44, 2110-2121.

39. Rapp, A.; Knipser, W. Eine Neue Methode zur Anreicherung von Dampfkomponenten. Dargestellt am Beispiel des Weines. Chromatographia 1980, 13, 698-702.

40. Cappellin, L.; Loreto, F.; Aprea, E.; Romano, A.; del Pulgar, J.; Gasperi, F.; Biasioli, F. PTR-MS in Italy: A Multipurpose Sensor with Applications in Environmental, Agri-Food and Health Science. Sensors 2013, 13, 11923-11955.

41. Schwab, W.; Davidovich-Rikanati, R.; Lewinsohn, E. Biosynthesis of plant-derived flavor compounds. Plant J. 2008, 54, 712-732. 
42. Rohmer, M. Mevalonate-independent methylerythritol phosphate pathway for isoprenoid biosynthesis. Elucidation and distribution. Pure Appl. Chem. 2003, 75, 375-387.

43. Aharoni, A.; Giri, A.P.; Verstappen, F.W.A.; Bertea, C.M.; Sevenier, R.; Sun, Z.; Jongsma, M.A.; Schwab, W.; Bouwmeester, H.J. Gain and Loss of Fruit Flavor Compounds Produced by Wild and Cultivated Strawberry Species. Plant Cell Online 2004, 16, 3110-3131.

44. Hampel, D.; Swatski, A.; Mosandl, A.; Wüst, M. Biosynthesis of Monoterpenes and Norisoprenoids in Raspberry Fruits (Rubus idaeus L.): The Role of Cytosolic Mevalonate and Plastidial Methylerythritol Phosphate Pathway. J. Agric. Food Chem. 2007, 55, 9296-9304.

45. El Hadi, M.A.M.; Zhang, F.-J.; Wu, F.-F.; Zhou, C.-H.; Tao, J. Advances in Fruit Aroma Volatile Research. Molecules 2013, 18, 8200-8229.

46. Winterhalter, P.; Rouseff, R. Carotenoid-Derived Aroma Compounds: An Introduction. In Carotenoid-Derived Aroma Compounds; ACS Symposium Series; American Chemical Society: Washington, DC, USA, 2001; Volume 802, pp. 1-17.

47. Breitmaier, E. Terpenes: Flavors, Fragrances, Pharmaca, Pheromones; John Wiley \& Sons: Weinheim, Germany, 2006.

48. Maicas, S.; Mateo, J.J. Hydrolysis of terpenyl glycosides in grape juice and other fruit juices: A review. Appl. Microbiol. Biotechnol. 2005, 67, 322-335.

49. Gunata, Y.Z.; Bayonove, C.L.; Baumes, R.L.; Cordonnier, R.E. The aroma of grapes I. Extraction and determination of free and glycosidically bound fractions of some grape aroma components. J. Chromatogr. A 1985, 331, 83-90.

50. Krammer, G.; Winterhalter, P.; Schwab, M.; Schreier, P. Glycosidically bound aroma compounds in the fruits of Prunus species: Apricot (P. armeniaca, L.), peach (P. persica, L.), yellow plum (P. domestica, L. ssp. syriaca). J. Agric. Food Chem. 1991, 39, 778-781.

51. Pabst, A.; Barron, D.; Etievant, P.; Schreier, P. Studies on the enzymic hydrolysis of bound aroma constituents from raspberry fruit pulp. J. Agric. Food Chem. 1991, 39, 173-175.

52. Boido, E.; Lloret, A.; Medina, K.; Fariña, L.; Carrau, F.; Versini, G.; Dellacassa, E. Aroma Composition of Vitis vinifera Cv. Tannat: the Typical Red Wine from Uruguay. J. Agric. Food Chem. 2003, 51, 5408-5413.

53. Finefield, J.M.; Sherman, D.H.; Kreitman, M.; Williams, R.M. Enantiomeric Natural Products: Occurrence and Biogenesis. Angew. Chem. Int. Ed. 2012, 51, 4802-4836.

54. Brenna, E.; Fuganti, C.; Serra, S. Enantioselective perception of chiral odorants. Tetrahedron-Asymmetry 2003, 14, 1-42.

55. Mosandl, A. Authenticity Assessment: A Permanent Challenge in Food Flavor and Essential Oil Analysis. J. Chromatogr. Sci. 2004, 42, 440-449.

56. Casabianca, H.; Graff, J.B. Enantiomeric and isotopic analysis of flavour compounds of some raspberry cultivars. J. Chromatogr. A 1994, 684, 360-365.

57. Nitz, S.; Kollmannsberger, H.; Weinreich, B.; Drawert, F. Enantiomeric distribution and 13C/12C isotope ratio determination of $\gamma$-lactones: Appropriate methods for the difterentiation between natural and non-natural flavours? J. Chromatogr. A 1991, 557, 187-197.

58. Werkhoff, P.; Bretschneider, W.; Güntert, M.; Hopp, R.; Surburg, H. Chirospecific analysis in flavor and essential oil chemistry Part B. Direct enantiomer resolution of frans- $\alpha$-ionone and trans- $\alpha$-damascone by inclusion gas chromatography. Z. Lebensm.-Unters. Forch. 1991, 192, 111-115. 
59. Sewenig, S.; Bullinger, D.; Hener, U.; Mosandl, A. Comprehensive Authentication of (E)- $\alpha(\beta)$-Ionone from Raspberries, Using Constant Flow MDGC-C/P-IRMS and Enantio-MDGC-MS. J. Agric. Food Chem. 2005, 53, 838-844.

60. Prasanna, V.; Prabha, T.N.; Tharanathan, R.N. Fruit Ripening Phenomena-An Overview. Crit. Rev. Food Sci. Nutr. 2007, 47, 1-19.

61. Davies, D.D. The Biochemistry of Plants: Biochemistry of Metabolism; Academic Press: London, UK, 1987.

62. Guichard, E. Formation of Volatile Components of 2 Raspberry Cultivars during the Ripening. Sci. Aliments 1984, 4, 459-472.

63. Fall, R.; Karl, T.; Hansel, A.; Jordan, A.; Lindinger, W. Volatile organic compounds emitted after leaf wounding: On-line analysis by proton-transfer-reaction mass spectrometry. J. Geophys. Res. 1999, 104, 15963-15974.

64. Soukoulis, C.; Cappellin, L.; Aprea, E.; Costa, F.; Viola, R.; Märk, T.D.; Gasperi, F.; Biasioli, F. PTR-ToF-MS, A Novel, Rapid, High Sensitivity and Non-Invasive Tool to Monitor Volatile Compound Release During Fruit Post-Harvest Storage: The Case Study of Apple Ripening. Food Bioprocess Technol. 2013, 6, 2831-2843.

65. Borejsza-Wysocki, W.; Hrazdina, G. Biosynthesis of p-hydroxyphenylbutan-2-one in raspberry fruits and tissue cultures. Phytochemistry 1994, 35, 623-628.

66. Borejsza-Wysocki, W.; Goers, S.K.; McArdle, R.N.; Hrazdina, G. (p-Hydroxyphenyl)butan-2-one levels in raspberries determined by chromatographic and organoleptic methods. J. Agric. Food Chem. 1992, 40, 1176-1177.

67. Rothe, M. Introduction to Aroma Research; Kluver Academic Publishers: Dordrecht, The Netherlands, 1988.

68. Fehr, C.; Guntern, O. Efficient Synthesis of Enantiomerically Pure $\alpha$-Ionone from (R)- and (S)- $\alpha$-Damascone. HCA 1992, 75, 1023-1028.

69. Jaeger, S.R.; McRae, J.F.; Bava, C.M.; Beresford, M.K.; Hunter, D.; Jia, Y.; Chheang, S.L.; Jin, D.; Peng, M.; Gamble, J.C.; et al. A Mendelian Trait for Olfactory Sensitivity Affects Odor Experience and Food Selection. Curr. Biol. 2013, 23, 1601-1605.

70. Grosch, W. Detection of potent odorants in foods by aroma extract dilution analysis. Trends Food Sci. Technol. 1993, 4, 68-73.

71. Wang, Y.; Finn, C.; Qian, M.C. Impact of Growing Environment on Chickasaw Blackberry (Rubus L.) Aroma Evaluated by Gas Chromatography Olfactometry Dilution Analysis. J. Agric. Food Chem. 2005, 53, 3563-3571.

72. Cappellin, L.; Aprea, E.; Granitto, P.; Romano, A.; Gasperi, F.; Biasioli, F. Multiclass methods in the analysis of metabolomic datasets: The example of raspberry cultivar volatile compounds detected by GC-MS and PTR-MS. Food Res. Int. 2013, 54, 1313-1320.

73. Xu, X.; Wedgwood, E.; Berrie, A.M.; Allen, J.; O’Neill, T.M. Management of raspberry and strawberry grey mould in open field and under protection. A review. Agron. Sustain. Dev. 2012, $32,531-543$.

74. Kliebenstein, D.J.; Rowe, H.C.; Denby, K.J. Secondary metabolites influence Arabidopsis/Botrytis interactions: variation in host production and pathogen sensitivity. Plant J. 2005, 44, 25-36. 
75. Vaughn, S.F.; Spencer, G.F.; Shasha, B.S. Volatile compounds from raspberry and strawberry fruit inhibit postharvest decay fungi. J. Food Sci. 2006, 58, 793-796.

76. Wang, C.Y. Maintaining postharvest quality of raspberries with natural volatile compounds. Int. J. Food Sci. Technol. 2003, 38, 869-875.

77. Fallik, E.; Archbold, D.D.; Hamilton-Kemp, T.R.; Clements, A.M.; Collins, R.W.; Barth, M.M. (E)-2-Hexenal Can Stimulate Botrytis cinerea Growth in vitro and on Strawberries in vivo during Storage. J. Am. Soc. Hortic. Sci. 1998, 123, 875-881.

78. Neri, F.; Cappellin, L.; Spadoni, A.; Cameldi, I.; Algarra Alarcon, A.; Aprea, E.; Romano, A.; Gasperi, F.; Biasioli, F. Role of strawberry volatile organic compounds in the development of Botrytis cinerea infection. Plant Pathol. 2014, doi:10.1111/ppa.12287.

79. Graham, J.; Smith, K.; Tierney, I.; MacKenzie, K.; Hackett, C.A. Mapping gene H controlling cane pubescence in raspberry and its association with resistance to cane botrytis and spur blight, rust and cane spot. Theor. Appl. Genet. 2006, 112, 818-831.

80. Johnston, D.J.; Ramanathan, V.; Williamson, B. A Protein from Immature Raspberry Fruits which Inhibits Endopolygalacturonases from Botrytis cinerea and other Micro-organisms. J. Exp. Bot. 1993, 44, 971-976.

81. Chambers, E.; Koppel, K. Associations of Volatile Compounds with Sensory Aroma and Flavor: The Complex Nature of Flavor. Molecules 2013, 18, 4887-4905.

82. Zini, E.; Biasioli, F.; Gasperi, F.; Mott, D.; Aprea, E.; Märk, T.; Patocchi, A.; Gessler, C.; Komjanc, M. QTL mapping of volatile compounds in ripe apples detected by proton transfer reaction-mass spectrometry. Euphytica 2005, 145, 269-279.

83. Dunemann, F.; Ulrich, D.; Boudichevskaia, A.; Grafe, C.; Weber, W.E. QTL mapping of aroma compounds analysed by headspace solid-phase microextraction gas chromatography in the apple progeny 'Discovery' $\times$ 'Prima'. Mol. Breed. 2009, 23, 501-521.

84. Costa, F.; Cappellin, L.; Zini, E.; Patocchi, A.; Kellerhals, M.; Komjanc, M.; Gessler, C.; Biasioli, F. QTL validation and stability for volatile organic compounds (VOCs) in apple. Plant Sci. 2013, $211,1-7$.

(C) 2015 by the authors; licensee MDPI, Basel, Switzerland. This article is an open access article distributed under the terms and conditions of the Creative Commons Attribution license (http://creativecommons.org/licenses/by/4.0/). 